\title{
Review: computer vision applied to the inspection and quality control of fruits and vegetables
}

\author{
Revisão: visão computacional aplicada à inspeção \\ e ao controle da qualidade de frutas e verduras
}

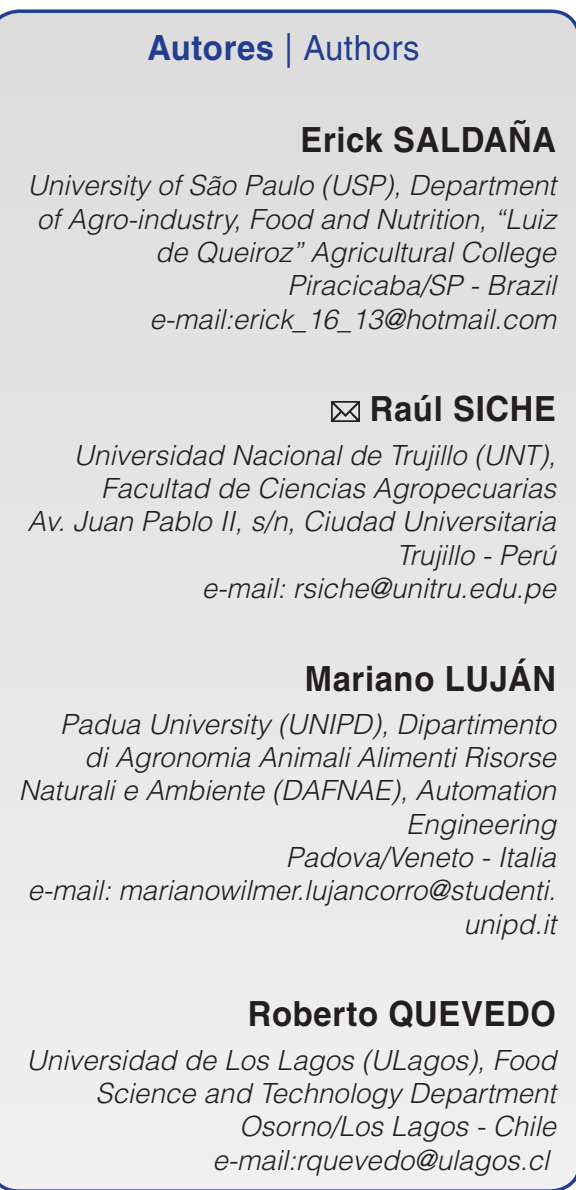

$\checkmark$ Autor Correspondente / Corresponding Author

Recebido / Received: 07/06/2013 Aprovado / Approved: 02/12/2013 Publicado / Published: dez./2013

\section{Summary}

This is a review of the current existing literature concerning the inspection of fruits and vegetables with the application of computer vision, where the techniques most used to estimate various properties related to quality are analyzed. The objectives of the typical applications of such systems include the classification, quality estimation according to the internal and external characteristics, supervision of fruit processes during storage or the evaluation of experimental treatments. In general, computer vision systems do not only replace manual inspection, but can also improve their skills. In conclusion, computer vision systems are powerful tools for the automatic inspection of fruits and vegetables. In addition, the development of such systems adapted to the food industry is fundamental to achieve competitive advantages.

Key words: Computer vision; Image analysis; Automatic inspection; Quality control; Real time.

\section{Resumo}

Este trabalho apresenta uma revisão da literatura existente, mais recente, sobre visão computacional aplicada à inspeção de frutas e verduras. Foram analisadas as técnicas mais empregadas para estimar diversas propriedades relacionadas com a qualidade. Os objetivos das aplicações típicas de tais sistemas incluem a classificação, a estimativa da qualidade segundo características internas ou externas, o seguimento dos processos da fruta durante o armazenamento ou a avaliação de tratamentos experimentais. Em geral, um sistema de visão computacional não só pode substituir a inspeção manual, mas também melhorar suas capacidades. Conclui-se que os sistemas de visão computacional são potentes ferramentas para a inspeção automática da qualidade de frutas e verduras, e o desenvolvimento de sistemas deste tipo, adaptados à indústria de alimentos, é fundamental para adquirir vantagens competitivas.

Palavras-chave: Visão computacional; Análise de imagens; Inspeção automática; Controle de qualidade; Tempo real. 


\section{Introduction}

The application of computer vision in industry has increased considerably in recent years, and one can find applications in the terrestrial and aerial mapping of natural resources, crop monitoring, precision agriculture, robotics, automatic guiding, non-destructive inspection of product properties, quality control and sorting in processing lines and the general automation of processes (CUBERO, 2012). This wide range of applications is due to the fact that computer vision systems provide significant amounts of information about the nature or attributes of scene analyses. Furthermore, this technology allows for the possibility of studying scenes in regions of the electromagnetic spectrum in which the human eye is not sensitive, such as ultraviolet radiation (UV) or infrared spectral regions (ZUDE, 2008).

One area where the use of this technology has spread rapidly is in the inspection of food products (SUN, 2007; LORENTE et al., 2012) and in particular in the automatic inspection of fruits and vegetables. The quality of a piece of fruit or vegetable, fresh or processed, is defined by a series of physicochemical characteristics that make it more or less attractive to consumers, such as its maturity, size, weight, shape, colour, presence of dirt and diseases, presence or absence of stem, presence of seeds, sugar content, etc.. These features cover all the factors that influence the appearance of a product and may eventually include nutritional and sensory qualities or properties related to its conservation. Most of these factors have traditionally been evaluated by a visual inspection performed by qualified personnel, but today have mostly been replaced by commercial automatic inspection systems based on computer vision and image analysis (DU and SUN, 2006). In manual sorting processes, there is a relatively high risk of human error, and decisions made by workers can be affected by psychological factors such as fatigue or acquired habits. One study carried out with different varieties of apple, where qualified staff compared several parameters such as shape, size and colour, showed the limited human capacity to reproduce the estimation of quality, which the authors defined as "inconsistency" (PAULUS et al., 1997). Moreover quality requirements are increasing due to new governmental regulations and consumer market requests.

Computer vision is simplifying these tedious and subjective industrial quality control procedures. However, the automated inspection of agricultural production has some peculiarities and problems that other sectors of industrial production do not have, due to the biological nature of the products inspected. While manufactured products often exhibit similar colours, shapes, sizes and other external features, fruits and vegetables show a wide variety of characteristics. A fruit may show a different colour, size and shape from another, even if collected on the same day from the same tree. Food products naturally evolve in colour or texture after harvesting, and these characteristics depend on their maturity and their storage conditions (humidity and temperature, fungal infections, presence of volatile substances, storage duration, etc.). In addition, the colour of a particular area of the skin of a healthy fruit can match the colour of a spot on the surface of another fruit of the same variety. Moreover, it is essential to detect the presence of stems, leaves, dirt or any foreign material on quality control lines, and not confuse these with other skin blemishes. All this greatly complicates the development of algorithms capable of extracting quality decisions from image analyses, especially taking into account the fact that markets demand very fast image processing to achieve commercial production, so it is necessary to find a compromise between speed and precision.

This survey provides a comprehensive review of recent advances in computer vision inspection as applied to fruits and vegetables. It includes the analysis of the different technologies used, together with applications and developments intended for the external quality control of these products. The instructions are not only based on the analysis of images acquired in the visible spectrum but also on images obtained by ultraviolet induced fluorescence (UVIF) spectrum or acquired in the near infrared (NIR) spectrum. A review of other advanced techniques such as hyperspectral-image analysis, that produced by magnetic resonance (MR) and X-rays was also included, because such techniques now represent the most advanced technologies in this field and allow researchers to expand the scope of the inspection of fruits and vegetables to their internal quality characteristics.

\section{Theoretical support}

\subsection{Computer vision system}

Computer vision is the science that develops the theoretical groundwork and algorithms to extract and analyze automatically useful information about an object or set of objects observed (GUNASEKARAN, 1996; SUN, 2000; SUN and BROSNAN, 2003; ZHENG et al., 2006a, b; DU and SUN, 2006). In the inspection process and technical evaluation using electronic media, computer vision has the advantage of being fast, consistent, objective, non-invasive and inexpensive. In recent years, computer vision has been used to objectively measure the quality attributes of different food colours (BROSNAN and SUN, 2004; CUBERO et al., 2011; DU and SUN, 2004; JACKMAN et al., 2011).

Due to the huge diversity of shapes, textures and colours, the success of an online monitoring system of food depends largely on the hardware configuration of the computer vision system, which generally consists of 
Review: Computer vision applied to the inspection and quality control of fruits and vegetables

SALDAÑA, E. et al.

a lighting device, camera solid state (CCD), a personal computer monitor and a high-resolution colour device (Figure 1). The quality of the images to be captured is a direct function of two elements of the system: camera and illumination (lighting system).

While the camera is a commercial device where it is only necessary to choose the model that best fits the needs of each case, the lighting system can be created and configured in a specific way. Therefore the investigator must decide how to design and subsequently build the lighting system, depending on the particular application and the geometry of the object to be inspected.

\subsection{Lighting}

A good illumination system should provide uniform radiation across the scene, avoiding the presence of shine or shadows, and as far as possible must be spectrally uniform and stable over time. If the scene is not lit properly, it will increase the uncertainty and classification error, leading to the need for a pre-processing of the images, thus increasing the time required to analyze each image.

The arrangement of the light sources significantly affect the images acquired, due to the fact that some areas may receive more light than others, changing the total amount of radiation reflected from the objects in these areas. An uneven illumination can be corrected by calibrating the image using a white board of known reflectance (reference white), but this correction consumes some of the computational resources. Moreover, it is very important to consider the geometry of the inspected object. For example, directing the illumination at an angle of $45^{\circ}$ with respect to the vertical is effective when

\section{Detector}

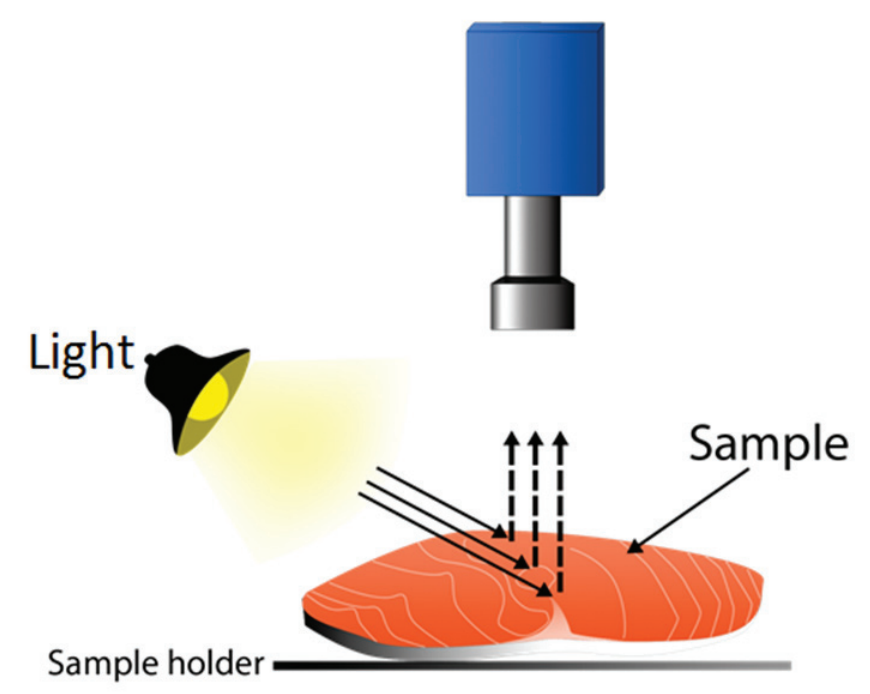

Figure 1. Schematic diagram of a computer vision system. a plane object is being illuminated, in order to avoid direct reflections on the camera. Fernandez et al. (2005) used this setting to illuminate apple slices to monitor and evaluate their dehydration based on colour and shape. Pedreschi et al. (2006) used a similar system to illuminate potato chips in a system designed to measure the kinetics of colour change under different frying temperatures.

Moreover, if the object is roughly spherical, it is more convenient to use a hemispherical diffuser device in order to illuminate it uniformly. Riquelme et al. (2008) used a device of this nature to illuminate and inspect olives. However, in these systems and in those which generally illuminate the object from above, the top of the object appears brighter than the edges, so creating a false change in intensity which must be corrected later. They proposed a methodology to correct this effect in citrus by constructing an elevation model of the fruit used to estimate the theoretical height and angle of the incidence of light for each pixel. This made it possible to estimate the appropriate corrections of the reflectance observed. Figure 2 shows two examples of lighting systems for illuminating spherical and flat objects.

A system can prevent unwanted glare and reflections on the objects by using a lighting system with polarizing filters and the use of cross-polarization techniques prevents the occurrence of specular reflection in the images. Blasco et al. (2007a) used this technique to avoid glare on the images of citrus fruit illuminated with fluorescent tubes, and thus estimated the colour and surface defects more accurately. When the object under inspection is translucent, or when the information is obtained from an analysis of its contour, back lighting can be used, which is achieved by placing the object between the light and the camera. Blasco et al. (2009a) adopted this solution for the online inspection of tangerine segments moving on semitransparent conveyor belts. By illuminating the slices from below, these images showed a vigorous contrast with the background, allowing for an easier morphological analysis of the contour, the seeds appearing darker than the rest of the wedge, facilitating their detection.

The emission spectrum of the light source is fundamental to the acquisition of a proper image. Fluorescent tubes are valid for applications where visible light is important (for example, sorting by colour), but produce little radiation in the infrared region. Moreover, with the use of conventional ballasts, there is a characteristic oscillation of the light intensity, an aspect that must be corrected by the use of high frequency electronic ballasts. Incandescent lamps emit more infrared radiation, but typically generate a lot of heat and have a low colour temperature, which is a major drawback in applications based on colour (CUBERO, 2012). 

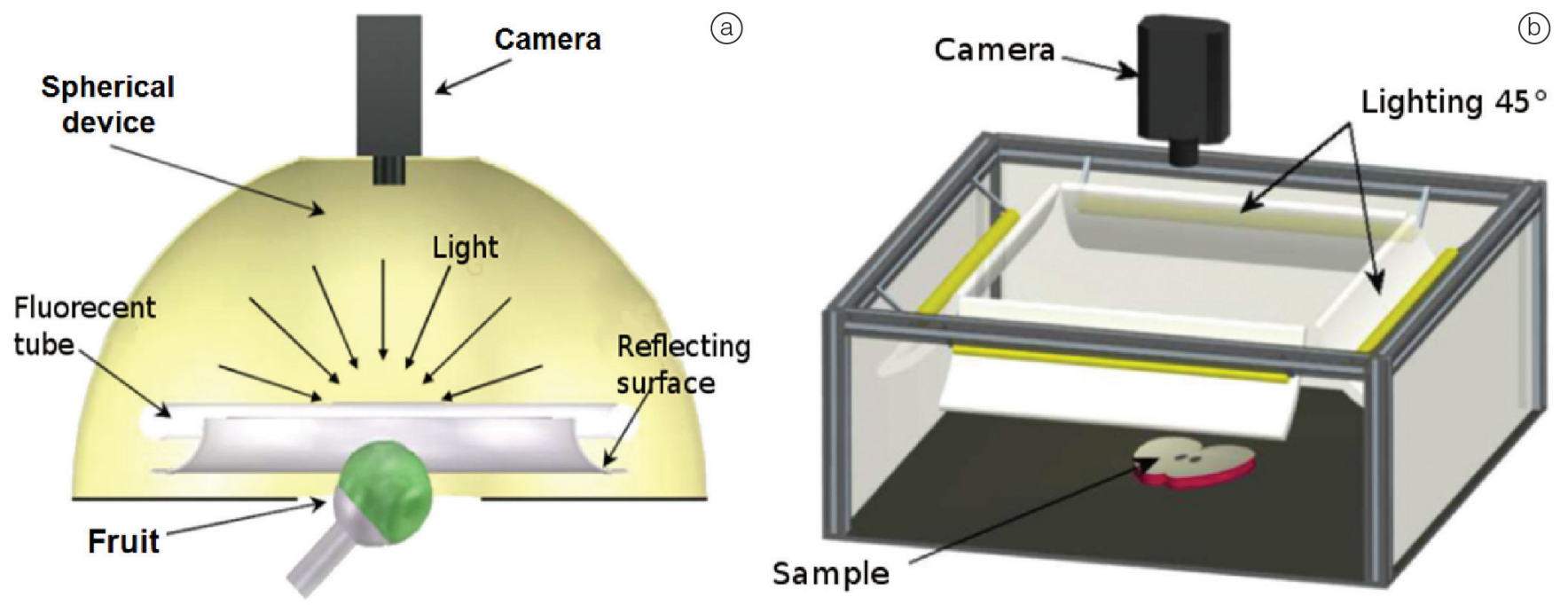

Figure 2.(a) Diffuse lighting (CUBERO, 2012) and (b) oriented directional sample $45^{\circ}$ (CUBERO, 2012).

Nowadays lighting systems based on light emitting diodes (LEDs) are becoming more frequent and economic. They usually have low power consumption, are robust and produce very little heat, but on the other hand, are directional and the light output is still quite limited.

In addition, special mention must be made of lighting systems that induce the phenomenon of fluorescence, due to the possible damage or production of invisible characteristics to the human eye. At certain wavelengths, the radiation received excites certain molecules, whose subsequent relaxation results in the body emitting lower energy radiation light (longer wavelengths). For example, induced fluorescence in the ultraviolet spectrum allows for certain types of external damage on fruits and produces fluorescence in the visible spectrum (CUBERO, 2012). Obenland and Neipp (2005) used the fluorescence of chlorophyll to locate incipient lesions on the skin caused by hot water treatments of lemons. Moreover, Ariana et al. (2006a) used UVIF to detect different types of defect in three varieties of apple. Light emission at $740 \mathrm{~nm}$, after UV excitation, allows for the detection of defects. Slaughter et al. (2008) used the same method to detect damage caused by frost, which is very difficult to detect with visible light. They obtained a success rate between $64 \%$ and $88 \%$, depending on the severity of the damage. Another application was that described by Lefcout and Kim (2006), using UVIF to detect contaminants in fruits such as apples, where they found that $668 \mathrm{~nm}$ was the peak fluorescence response from contaminants.

Table 1 shows a review of the different applications of computer vision in fruits and vegetables, including the spectral range data, the technique used and the resulting accuracy.

\subsection{Image acquisition}

The cameras are devices that acquire images, converting the light received from the scene into electronic signals. The most popular industrial cameras are based on CCD, which consist of a series of sensors (pixels), each of which is composed of a photocell and a capacitor (PETERSON, 2001). The charge acquired by the capacitor depends on the amount of light received by the photocell. These charges are converted to voltage and then into video signals. Some cameras are based on a linear CCD, consisting of a one-dimensional array of sensors that acquire a narrow strip of the scene. These cameras, known as linear scan cameras are suitable for applications where the object moves under the camera or where the camera moves over the object, so that the complete picture of its surface is acquired gradually, line to line. However, matrix cameras are the ones most commonly used in commercial applications. These take on a scene using a CCD in a two-dimensional matrix. Colour cameras can be built with a single $C C D$, consisting of pixels that are sensitive to the primary bands of red, green and blue (RGB), but more sophisticated, high quality cameras are also available, with three CCD. In these cameras, the light coming through the main lens is divided into three light beams through a series of lenses and mirrors, which create three copies of the scene, one from the red filter, another from the green filter and the third from the blue filter. After each filter there is a monochrome CCD sensor, so that each acquires a single RGB signal. The newest cameras are based on the complementary metal oxide semiconductor (CMOS) system. The integration with semiconductors has increased the density of the sensors, allowing for rapid technological development. These sensors have lower power consumption and lower manufacturing costs, and 
Review: Computer vision applied to the inspection and quality control of fruits and vegetables

SALDAÑA, E. et al.

Table 1. The application of computer vision in the quality and safety evaluation of fruits and vegetables.

\begin{tabular}{|c|c|c|c|c|c|}
\hline Products & Applications & $\begin{array}{l}\text { Spectral } \\
\text { range }\end{array}$ & Analysis & Precision & References \\
\hline \multirow{14}{*}{ Apple } & $\begin{array}{c}\text { Firmness and soluble } \\
\text { solids content }\end{array}$ & $500-1040$ & $\begin{array}{l}\text { Artificial neural } \\
\text { networks }\end{array}$ & $0.74-0.94$ & Noh and Lu (2007) \\
\hline & $\begin{array}{c}\text { Firmness and soluble } \\
\text { solids content }\end{array}$ & $680-950$ & $\begin{array}{l}\text { Multiple linear } \\
\text { regression }\end{array}$ & $0.88-0.89$ & Peng and Lu (2008) \\
\hline & $\begin{array}{c}\text { Firmness and soluble } \\
\text { solids content }\end{array}$ & $500-1000$ & $\begin{array}{l}\text { Multiple linear } \\
\text { regression }\end{array}$ & $0.75-0.86$ & Qin et al.(2009) \\
\hline & Detection of stains & $400-1000$ & $\begin{array}{c}\text { Principal component } \\
\text { analysis }\end{array}$ & $93.95 \%$ & EIMasry et al. (2008) \\
\hline & Detection of stains & $400-1000$ & $\begin{array}{l}\text { Principal component } \\
\text { analysis }\end{array}$ & $86.00 \%$ & Xing and De Baerdemaeker (2005) \\
\hline & Detection of stains & $400-1000$ & $\begin{array}{c}\text { Principal component } \\
\text { analysis }\end{array}$ & $86.36 \%$ & Xing et al.(2007) \\
\hline & $\begin{array}{l}\text { Detection of bitter } \\
\text { spots }\end{array}$ & $900-1700$ & $\begin{array}{l}\text { Least squares } \\
\text { regression }\end{array}$ & - & Nicolai et al. (2006) \\
\hline & Chilling injury & $400-1000$ & $\begin{array}{c}\text { Artificial neural } \\
\text { networks }\end{array}$ & $98.40 \%$ & ElMasry et al. (2008) \\
\hline & Stem/Chalice & $400-1000$ & $\begin{array}{c}\text { Principal component } \\
\text { analysis }\end{array}$ & $98-100 \%$ & Xing et al. (2007) \\
\hline & Sugar content & $685-900$ & $\begin{array}{l}\text { Least squares } \\
\text { regression }\end{array}$ & 0.91 & Zhao et al. (2009) \\
\hline & Starch Index & $1000-1700$ & $\begin{array}{c}\text { Discriminant analysis } \\
\text { of partial least } \\
\text { squares }\end{array}$ & $80.80 \%$ & Menesatti et al. (2009) \\
\hline & Sugar content & $650-1000$ & $\begin{array}{l}\text { Least squares } \\
\text { regression }\end{array}$ & 0.97 & Guo et al. (2007) \\
\hline & Internal defects & $400-1000$ & $\begin{array}{c}\text { Discriminant analysis } \\
\text { of partial least } \\
\text { squares }\end{array}$ & $99 \%$ & Ariana et al. (2006b) \\
\hline & Chilling injury & $447-951$ & Nearest neighbours & $93.30 \%$ & Cheng et al. (2004) \\
\hline \multirow{2}{*}{$\begin{array}{c}\text { Strawberry } \\
\text { Peach } \\
\text { Cucumbers }\end{array}$} & $\begin{array}{l}\text { Internal defects and } \\
\text { colour }\end{array}$ & $400-1000$ & $\begin{array}{c}\text { Principal component } \\
\text { analysis }\end{array}$ & $86 \%$ & Ariana and Lu (2010) \\
\hline & Chilling injury & $900-1000$ & $\begin{array}{l}\text { Principal component } \\
\text { analysis and Linear } \\
\text { discriminant analysis }\end{array}$ & - & Gowen et al. (2009) \\
\hline
\end{tabular}

are currently being widely implemented in webcams and mobile devices (CUBERO, 2012).

Frequently the inspection of products or specific features requires image acquisition systems that are sensitive to different wavelengths throughout the spectrum. In these cases, multispectral cameras can be used, which combine various visible and invisible bands using appropriate filters and sensors. Aleixos et al. (2002) developed a multispectral camera for image acquisition in the visible and NIR spectra of the same scene, in order to inspect citrus fruit using an automatic sorting machine. Lleó et al. (2009) used a camera sensitive to three bands in the visible spectrum and to NIR in order to estimate the maturity of peaches. Throop et al. (2005) proposed a special camera designed to acquire images at 740 and
$950 \mathrm{~nm}$ in combination with visible images for classifying apples in real time. Unay and Gosselin (2006) used four band-pass interference filters centred at $450 \mathrm{~nm}, 500$ $\mathrm{nm}, 750 \mathrm{~nm}$ and $800 \mathrm{~nm}$ to detect defects in apples. More recently hyperspectral image acquisition systems have been used to inspect fruits and vegetables (SUN, 2010). These systems use narrow band filters to generate hyperspectral images composed of $n$ monochromatic images, each corresponding to the radiance / reflectance at a specific wavelength. Depending on the technology used there are different hyperspectral image acquisition systems, the three most popular being the image spectrographs (POLDER et al., 2001), the acoustic-optical tunable filters (FSAO) (BEl et al., 2004) and the liquid crystal tunable filters (LCTF) (EVANS et al., 1998). 
Image spectrographs separate the reflection of a narrow zone of the scene into its spectral components via a prism or grating, and project the spectral information to an image sensor, which usually consists of a CCD camera or linear scanning CMOS (KIM et al., 2001). A FSAO is an electronically adjustable band pass spectral filter formed of a glass which, when excited by an acoustic wave, refracts a certain ampleness and is thus is separated from the rest of the light spectrum. The wavelength of the light is separated based on the frequency of the acoustic signal applied by the glass, and the LCTF operation is based on the combination of Lyot filters. These filters consist of a sandwich structure comprising a liquid crystal sheet and a quartz sheet between two linear polarizers, the quartz sheet and the liquid crystal constituting a retarder. The main success of the Lyot filter is the electronic control of the process of interference between ordinary and extraordinary beams of the incident radiation, producing the desired frequency selectivity in the transmitted radiation (HECHT, 1998). A LCTF comprises a series of stacked Lyot filters, thus achieving the range and selectivity at the desired frequency. All these systems can be sensitive to approximately $2500 \mathrm{~nm}$, and it is important that both the spectrograph or filter and the camera used are sensitive in the same spectral range.

Although there are several examples of the application of hyperspectral systems in other fields, their incorporation in commercial food product warehouses is very complicated, due to the high cost of the computational system required for the acquisition and processing of these images. Some applications include that developed by Nicolai et al. (2006) to find certain types of damage in apples using the infrared region, and that developed by Karimi et al. (2009), who studied the changes in reflectance (350 to $2500 \mathrm{~nm}$ ) of avocados coated with various formulations.

Increasing computing power and improved imaging technology have prompted the use of high resolution images, which result in increased performance of the computer vision systems. Today it is possible to detect defects as small as a few $\mathrm{mm}^{2}$. According to Cubero et al. (2012), another important step is related to the high-speed protocols such as the universal serial bus (USB) 2.0 (up to $480 \mathrm{Mbps}$ ), the Apple FireWire serial bus (800 Mbps) or Giga-Ethernet (1000 Mbps), which allow the rapid transfer of these large images to the computer. Some of these are even faster than the image acquisition cards previously used on the bus peripheral component interconnect (PCI) (133 Mbps).These advances have changed the traditional architecture consisting of a video camera connected to an image acquisition card installed in a computer, creating a new architecture in which there is direct communication between the camera and computer. Even new smart cameras are appearing, which incorporate a microprocessor with an operating system with which the user can develop software for image processing. Thus the camera also becomes a processing unit and does not need an additional computer. Furthermore, the use of the Internet has increased the availability of so-called IP cameras, which are able to transfer images to a remote computer via Internet.

In addition to traditional systems that acquire images using cameras, flatbed scanner shave also been used to get images of small objects such as nuts or leaves (MENESATTI et al., 2008), and even medical equipment for the analysis of the internal quality of fruit and vegetables, such as those based on X-ray or magnetic resonance (HERNÁNDEZ-SÁNCHEZ et al., 2007; MILCZAREK et al., 2009).

Regarding the format of the images, if these are to be stored for subsequent processing, the format that is stored may affect subsequent processing of the images. Compression formats such as the Joint Photographic Group (JPEG), take advantage of the inherent limitations of the human eye to discard non-appreciable information, which makes them useful in applications where the size of the storage memory is relevant (CUBERO, 2012). However, this format reduces the information available in the image and generates some noise, which may complicate subsequent image processing. The formats that do not reduce the image quality, such as the Tagged Image File Format (TIFF) or Bit Mapped Picture (BMP), are recommended for applications where such a loss of information is an important factor. In any case, online applications do not require the storage of images, but are acquired, processed and instantly discarded (CUBERO, 2012).

\subsection{Image processing techniques}

\subsubsection{Colour space transformations}

There are three aspects that determine colour, namely the type of emission source that irradiates an object, the physical properties of the object itself (which reflects the radiation consequently detected by the sensor), and the in-between medium (e.g., air or water) (MENESATTI et al., 2012). In general, a computer vision system captures the colour of each pixel within the image of the object using three colour sensors (or one sensor with three alternating filters) per pixel (FORSYTH and PONCE, 2003). The RGB model is the most often used colour model, in which each sensor captures the intensity of the light in the red $(R)$, green $(G)$ or blue $(B)$ spectrum, respectively (LEÓN et al., 2006). However, the RGB model is device-dependent and not identical to the intensities of the CIE system. Another problem with the RGB model is that it is not a perceptually uniform space. The differences between colours (i.e., Euclidean 
distances) in the RGB space do not correspond to colour differences as perceived by humans (PASCHOS, 2001). Standard RGB (sRGB; red, green, blue) and $L^{*} a^{*} b^{*}$ are commonly applied in quantifying standard food colours (MENESATTI et al., 2012). sRGB is an independent colour model device whose tri-stimulus values (sR, sG, $\mathrm{sB}$ ) reproduce the same colour in different devices, and represent linear combinations of the CIE XYZ. It is therefore used to define the mapping between RGB (non-linear signals) from a computer vision system and a deviceindependent system such as CIE XYZ (MENDOZA et al., 2006). sRGB is calculated based on the D65 illumination conditions, RGB values measured by computer vision, and a power function with a gamma value of 2.4. The camera sensors (e.g., CCD or CMOS) generate output signals and the rendering is device-dependent, since the display device specifications have different ranges of colour. In order to overcome this problem, the sRGB values are often transformed into other colour systems such as $L^{*} a^{*} b^{*}$ (MENESATTI et al., 2012).

\subsubsection{Colour calibration methods}

The quality of digital image is principally defined by its reproducibility and accuracy; without reproducibility and accuracy of the images, any attempt to measure the colour or geometric properties is of little use (VAN POUCKE et al., 2010). In general, a computer vision camera employs a single array of light-sensitive elements on a CCD chip, with a filter array that allows some elements to see red (R), some green (G) and some blue (B). 'White balance' is carried out to measure relative intensities manually or automatically (MENDOZA et al., 2006). A digital colour image is then generated by combining three intensity images in the range from 0-255. Since they are device-dependent, the RGB signals produced by different cameras are different for the same scene. These signals will also change with time since they are dependent on the camera settings and scenes (VAN POUCKE et al., 2010).

\subsubsection{Colour constancy and illumination estimation}

Colour constancy is the phenomenon by which perceived object colour tends to stay constant under changes in illumination. Colour constancy is not a property of the objects; it is a perceptual phenomenon, the result of mechanisms in the eye and brain (HURLBERT, 2007). Colour constancy is important for object recognition, scene understanding and image reproduction as well as for digital photography (LI et al., 2009). There are three factors affecting the image recorded by a camera, namely the physical content of the scene, the illumination incident on the scene, and the characteristics of the camera (BARNARD et al., 2002). An object can appear to be a different colour due to changes in the illumination. The objective of computational colour constancy is to find a nontrivial illuminant invariant description of a scene from an image taken under unknown lighting conditions, either by directly mapping the image to a standardized illuminant invariant representation, or by determining a description of the illuminant which can be used for subsequent colour correction of the image (BARNARD et al., 2002). The procedure of computational colour constancy includes two steps: estimating illumination parameters and using these parameters to get the colour of the objects under a known canonical light source. The first step, illumination estimation, is important in colour constancy computation. So far, a number of leading colour constancy algorithms have been proposed that focus on the illumination estimation. These algorithms can generally be divided into two major groups: unsupervised approaches and supervised ones. The algorithms falling into the first category include Max RGB, the grey world algorithm, Shades of grey (SoG), and Grey surface identification (GSI). The other colour constancy category includes the training-based solutions such as Bayesian colour constancy, Neural Network method and the support vector regression.

\section{Applications in the inspection and control of quality characteristics}

The ultimate purpose in many computer vision based inspection systems is to estimate one or several features of interest of the products at a particular time, and relate them to the consumer who appreciates quality. Other systems are designed to determine the evolution of the product in time in order to determine whether one particular treatment or process is valid or not. In most of these applications, image analysis is used to evaluate characteristics such as colour, size, shape, texture or the presence of damage (CUBERO, 2012). This review presents some of the research in computer vision for the external quality assessment of foods.

\subsection{Colour}

Colour is visually one of the most important parameters in define the quality of any food, and its evaluation has always been crucial and a theme of concern in the food industry as well as in food research and development. In this context the sensory properties of food such as its appearance and surface colour, which are the first parameters visually evaluated, consequently have a relationship with consumer acceptance or rejection of the product even before it enters the mouth. Currently, new tools are being used to measure changes in the colour characteristics of food, the computer vision technique being projected as an alternative to sensory evaluation. The efficient use of computer vision techniques to assess food colour and quality requires a calibration process based on absolute colour in a format of common 
interchange for colour data, since knowledge of the image characteristics could correlate better with product quality.

Colour is one of the most important attributes in fruits and vegetables because it directly influences the consumer decision to accept or reject a particular product. Thus producers strive to prevent colour defects in the products that reach the market, and to ensure that the different batches of products (for example canned, bagged, etc.) show similar colours. In the industry, colour is measured using a colorimeter (HOFFMAN, 2000). The colour coordinates provided by these devices usually refer to the colour space of the International Commission of Illumination (CIE) 1931, and are denoted by X, Y and $Z$. Colorimeters are used to measure small regions or in applications where the sample has a uniform colour, and are not well adapted to the measurement of objects with heterogeneous colours (GARDNER, 2007). When it is necessary to measure the colour of larger areas or if the sample contains distinctly different colours, one must measure the colour in a different way. Image analysis could be an effective solution, since the camera provides images where the colours of the pixels are determined individually. It should be mentioned that whereas colorimeters are easy to calibrate devices, the calibration of image analysis depends on many factors and is more complex.

The colour of a pixel in an image is expressed by three coordinates in a colour space. The most widely used in computers and digital images are the spaces based on the primary colours red, green and blue. When the objects inspected have different colours, a simple relationship between them can frequently discriminate them, which saves processing time. For example, Blasco et al. (2009c) used the colour space to discriminate four categories of pomegranate arils and classify them in real time. The tests showed that a model based on discriminate analysis using RGB coordinates as the variables provided the same classification results as a thresholding carried out on the $\mathrm{R} / \mathrm{G}$, with success rates exceeding $90 \%$. This latter method greatly reduced the processing time and was easy for an operator to grasp in the case of developing an industrial application.

It is important to highlight that the RGB colour space is dependent on the device. In other words, different devices produce different RGB values for the same pixels at a scene. For this reason, there have been various attempts to standardize the values, such as the colour space called sRGB (STOKES et al., 1996). Another commonly used colour space in food inspection, which is closer to human colour perception, is the Hue, Saturation and Intensity (HSI) value. Blasco et al. (2007b) compared five colour spaces to identify external defects in citrus and obtained the best results with the HSI. Xiaobo et al. (2007) used both RGB and HSI for Fuji apples and classified them into four colour categories. Meanwhile,
Abdullah et al. (2006) transformed the HSI coordinates into RGB coordinates, and used the $\mathrm{H}$ component to classify starfruit into four maturity categories.

However, both RGB and HSI are non-uniform colour spaces. This means that the Euclidean distance between two colour points located in different regions of these spaces will not produce the same difference in perception as a standard observer. To try to solve this problem, uniform spaces were defined as the CIE $L^{*} a^{*} b^{*}$ and Hunter Lab (HUNTERLAB, 2001), which are usually used for colour comparisons (LEÓN et al., 2006). Mendoza et al. (2006) compared different colour spaces such as sRGB, the HSI and $L^{*} a^{*} b^{*}$ in terms of their suitability for colour quantification on curved surfaces, and showed the $L^{*} a^{*}$ $b^{*}$ to be more appropriate.

Sometimes it is sufficient to use a single coordinate of the $L^{*}, a^{*} b^{*}$ to establish a classification of the fruit. Liming and Yanchao (2010) used the $a^{*}$ coordinate to classify strawberries into three colour categories. In comparison with human selection, the system based on image analysis successfully reached $89 \%$. The hue angle and chroma are characteristics derived from the above mentioned uniform spaces. To analyze the colour of the mango, Kang and Trujillo (2008) quantified the effect of the curvature to calculate the hue angle and chroma, and demonstrated that the first one provided a valuable quantitative description of the colour and of the colour changes in batch like single mango with heterogeneous colours

It is frequently important to determine the colour of a fruit to determine subsequent postharvest treatments. For example, tangerines are frequently harvested when they are still green, and submit them to a de-greening treatment. In these cases, the fruit is stored in a chamber with a specific humidity and determined ethylene concentration. The duration of this treatment depends on the colour of the fruit at the time of harvesting, which is expressed as a standard colour index (JIMÉNEZCUESTA et al., 1981). In another investigation, Fathi et al. (2011) used image analysis to measure the influence of different osmotic treatments on the colour of kiwis. For this purpose, they converted the original RGB coordinates to $L^{*} a^{*} b^{*}$ to evaluate the colour differences. According to Xul et al. (2009), the colour of the skin frequently also reveals the symptoms of internal injuries in apples.

Computer vision systems also have a wide application in agronomical fields, a typical case being the estimation of crop yields. Okamoto and Lee (2009) were able to detect green citrus fruits on the tree between leaves with similar colours. For this purpose they used hyperspectral images in the range from 369 to $1042 \mathrm{~nm}$. Safren et al. (2007) also proposed a method based on computer vision for the automatic estimation of crop yields of Golden delicious apples from hyperspectral images 
taken at different stages of growth. Bulanon et al. (2009) pursued a similar objective applied to citrus fruit, although with a different approach, using a combination of images from the visible and thermal spectra, analyzed by two methods of image fusion. With this system they improved the detection of fruit and showed better performance as compared to the use of thermal imaging alone.

According to Saldaña et al. (2013), to convert the RGB colour space of an image obtained by a computer vision system, to the $L^{*} a^{*} b^{*}$ colour space, this must be done in two phases. The first phase involves the conversion from RGB to $X Y Z$, and the second phase from $X Y Z$ to the CIELab colour space. As a first step, the RGB values must be normalized to $r g b$ (values between 0 and 1) using Equations 1, 2 and 3 for each value of $R$, $G$ and $B$ respectively.

si $\frac{\mathrm{R}}{255}>0.04045 r=\left(\frac{\mathrm{R}+0.055}{1.055}\right)^{2.4} ;$ si $\frac{\mathrm{R}}{255} \leq 0.04045 \mathrm{r}=\frac{\mathrm{R}}{12.92}$

si $\frac{\mathrm{G}}{255}>0.04045 \mathrm{~g}=\left(\frac{\mathrm{G}+0.055}{1.055}\right)^{2.4} ; \mathrm{si} \frac{\mathrm{G}}{255} \leq 0.04045 \mathrm{~g}=\frac{\mathrm{G}}{12.92}$

si $\frac{\mathrm{B}}{255}>0.04045 \mathrm{~b}=\left(\frac{\mathrm{B}+0.055}{1.055}\right)^{2.4} ; \mathrm{si} \frac{\mathrm{B}}{255} \leq 0.04045 \mathrm{~b}=\frac{\mathrm{B}}{12.92}$

Subsequently, using the matrix $M$ for the D65-2 ${ }^{\circ}$ illuminant-observer(Equation 4), the values are converted from rgb values to $X Y Z$ values. The D65-2 illuminant-observer was used because it is the standard recommended by the CIE since it is more adapted to the illumination used.

$\left[\begin{array}{c}X \\ Y \\ Z\end{array}\right]=100 *[M]\left[\begin{array}{l}r \\ g \\ b\end{array}\right]$

Where:

$[M]=\left[\begin{array}{lll}0.4124 & 0.3576 & 0.1805 \\ 0.2126 & 0.7152 & 0.0722 \\ 0.0193 & 0.1192 & 0.9505\end{array}\right]$

Thus, developing Equation 4 and using matrix 5 , the values for $X, Y$ and $Z$ are obtained from Equation 6 .

$X=100 * r * 0.4124+100 * g * 0.3572+100 * b * 0.1805$
$Y=100 * r * 0.2126+100 * g * 0.7152+100 * b * 0.0722$
$Z=100 * r * 0.0193+100 * g * 0.1192+100 * b * 0.9505$

Subsequently the values for $\mathrm{x}, \mathrm{y}, \mathrm{z}$, are obtained using Equations 7, 8 and 9 respectively.

$x=\frac{x}{X n}$

$y=\frac{Y}{Y n}$
$\mathrm{z}=\frac{\mathrm{Z}}{\mathrm{Zn}}$

Where $\mathrm{Xn}, \mathrm{Yn}, \mathrm{Zn}$ are tri-stimulus values of the specific white object, in this case using illuminant D65 (daylight) and an observer with the values shown in Equation 10.

$X n=95.047 ; \quad Y n=100 ; Z n=108.883$

The values for: $\operatorname{var} X$; var $Y$; var $Z$, can then be calculated using Equations 11, 12 and 13.

si $x>0.008856 \operatorname{var} X=(x)^{1 / 3} ;$ si $x \leq 0.008856 \operatorname{var} X=\left(7.787^{*} x\right)+(16 / 116)$

si $y>0.008856 \operatorname{var} Y=(y)^{1 / 3} ;$ si $y \leq 0.008856 \operatorname{var} Y=\left(7.787^{*} y\right)+(16 / 116)$

si $z>0.008856 \operatorname{var} Z=(z)^{1 / 3} ;$ si $z \leq 0.008856 \operatorname{var} Z=\left(7.787^{*} z\right)+(16 / 116)$

Subsequently the values for $L^{*}, a^{*}$ and $b^{*}$ can be calculated in the CIELab colour space, using equation 14 to calculate the lightness $L^{*}$, equation 15 for the value of $a^{*}$ and equation 16 for the value of $b^{*}$.

$L^{*}=\left(116^{*} \operatorname{var} Y\right)-16$

$a^{*}=500 *(\operatorname{var} X-\operatorname{var} Y)$

$b^{*}=200(\operatorname{var} Y-\operatorname{var} Z)$

\subsection{Size and volume}

The size is a characteristic of particular importance in the food industry as the cost of many products is directly related to their size. The estimate of this attribute in regular objects, such as spherical or nearly spherical fruits is relatively easy, but it becomes more complex in fruits and vegetables with irregular shapes. The variables used to estimate the size are area, perimeter, length and width. Due to irregularities in the shape of natural agricultural products, the orientation of the object relative to the camera has an important influence when these measurements are estimated by image analysis. For this reason, many authors combine information obtained from images taken at different angles between the object and the camera. For example, Blasco et al. (2003) estimated the size of Golden delicious apples acquiring four images of each fruit, and choosing the view in which the stem was located closer to the centroid (center of mass) of the object, considering that the current regulations require the equatorial diameter to be used as the measurement of size. Throop et al. (2005) measured the size of 14 varieties of apple while they were being transported by rollers, adjusting the speed of rotation and translation such that the images captured were of one full turn of each fruit. Thus the equatorial diameter and the area of the apples 
Review: Computer vision applied to the inspection and quality control of fruits and vegetables

SALDAÑA, E. et al.

were calculated. Subsequently the apple was assumed to be an ellipse and the height estimated from its main axis, using this data to obtain the orientation of the fruit with respect to the camera.

The volume was also used as an indirect measurement of size, although it is a particularly difficult challenge to estimate the volume of natural objects starting from a flat image. According to Koc (2007), in the scientific literature one of the most frequently mentioned ways of estimating the volume of food products that present symmetry around their axes, is by using computer vision to subdivide the objects into different partitions. One method consists of obtaining the contour of the object from a flat projection and divided it into vertical sections of a predetermined width. Once this is done half of the height of each vertical section is rotated around the axis $X$, in order to obtain the width of the slices, for which it is simple to estimate the volume. The volumes of all the slices are then added up to estimate the total volume of the object. Koc (2007) determined the size of watermelons using this theory, and compared the results with those obtained using the traditional method of water displacement, concluding that the difference between the volumes estimated by imaging and by water displacement were not statistically significant.

\subsection{Shape}

The consumer is always more prone to purchase fruits or vegetables showing their characteristic shapes. Products with deformities or strange shapes cannot be traded or have to be sold at lower prices. Therefore the automatic quality control of these products must take this fact into account (CUBERO, 2012). The shape is a subjective measurement that can be estimated from the measurements of other features, and is frequently used to categorize the fruits.

Although there are many possibilities offered by new technologies to accurately measure the intrinsic quality of food products, human beings are more flexible and adaptable at evaluating and assessing the quality factors than the machines (PAULUS et al., 1997). Human visual inspection is invaluable in the classification operations of some food products (Figure 3).Computer vision is used in the construction of explicit and significant descriptions of physical properties, from images (BALLARD and BROWN, 1982).

There are some applications where computer vision is the only alternative, for example when wavelengths outside human sensibility, such as the NIR or X-rays, are used. Also, the increase in resolution of computer vision systems allows one to automatically detect human attributes that we cannot see (DUBOIS and GLANZ, 1986). To complete the picture, developed countries currently
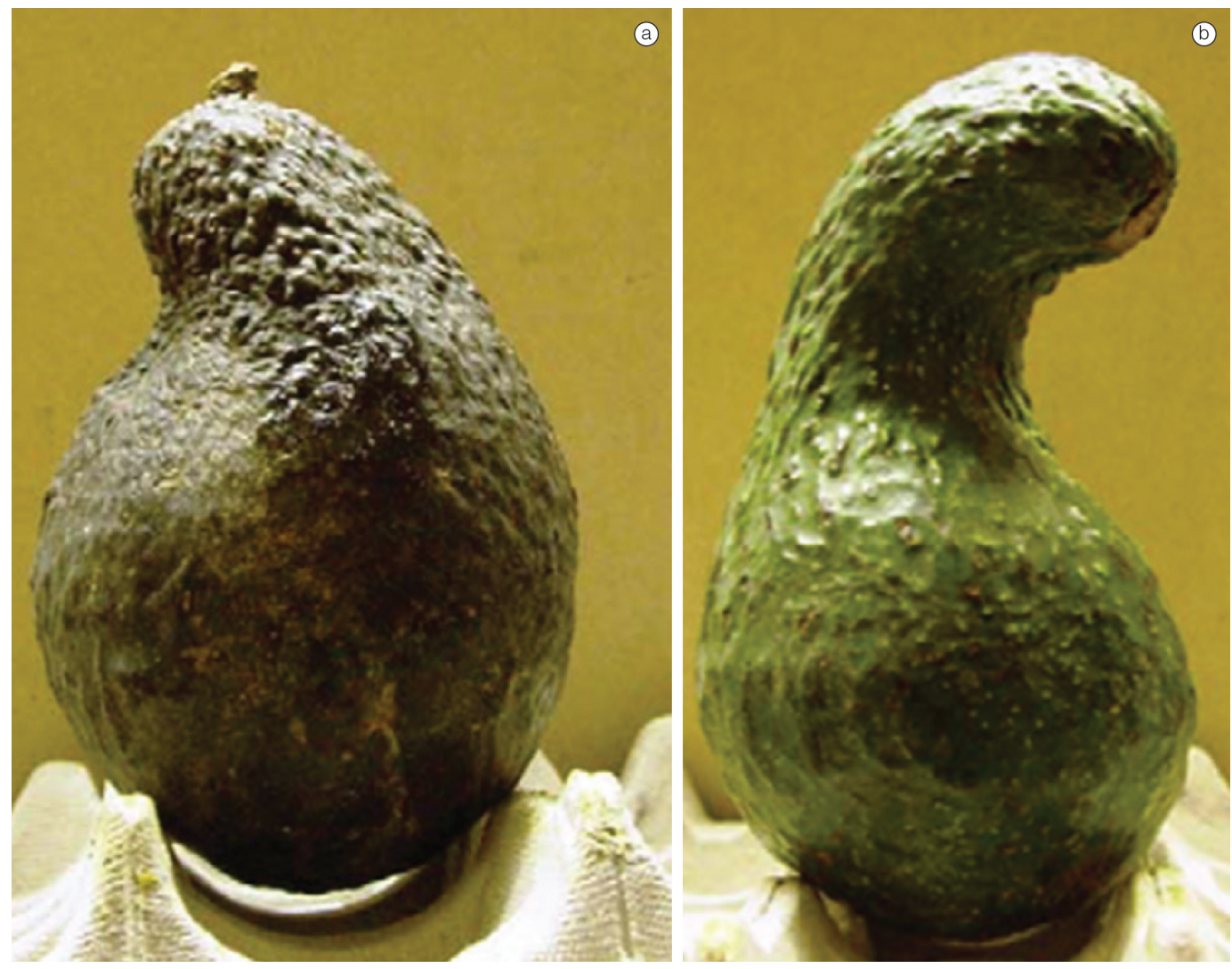

Figure 3. Anomalies in the shape of avocados, (a) crick-side;(b) crook-neck (Hofshi and Arpaia, 2002). 
have to confront the absence of manual labour willing to accept seasonal work and the low wages typically paid by a classification or packing installation. As a result, over the last two decades, the inspection of fresh fruits and vegetables using computer vision has been gaining ground over its counterpart, the use of manual labour, in most food industries in the developed countries. Today, on-line classification systems of fruits based on computer vision systems are common in the U.S. and European countries, Japan, Korea (KONDO, 2010), Canada, Australia and New Zealand. The parameters measured on-line by the computer vision system are the size, colour, shape and surface defects, such as spots or lesions. To give a complete overview of the technology it should be noted that at present the most promising branch of computer vision is the use of hyperspectral imaging, which combines spatial and spectral computer vision systems with the use of the spectrograph (KIM et al., 2007).

The descriptions of images made by man are usually abstract or artistic, not quantitative. As a result, identification of the shape of a fruit is easy for the brain, but difficult for a computer. The shapes of manufactured objects can be described using precise mathematical terms, while irregular shapes, such as biological products can be approximated by fitting to a curve. For example, Beyer et al. (2002) suggested the possibility of representing the two dimensional (2D) shape of a cherry by the cardioid, a special case of the Limaçon of Pascal. However, fruit sorting is not as strict as the inspection of industrial parts, so that in many situations it is necessary to find a curve that matches a given fruit, especially considering that the process of finding a curve takes time (YING et al., 2003). For example, Liming and Yanchao (2010) defined four classes of strawberry shape: longconical, square, conic and rounded. To estimate the shape of a strawberry, linear sequences (widths) are extracted from the contour of the fruit, and the length normalizing to eliminate the influence of size, in order to use the k-means method to assign each fruit to a respective class. Circularity is another feature which has been used to determine the shape of fruits (UNAY and GOSSELIN, 2007). Sadrnia et al. (2007) used the relationship of aspect (length by width) to estimate the shape of watermelons. Furthermore, they used the correlation coefficients of the parameters of estimated mass, volume, size, density, sphericity coefficient and average diameter to generate a model to determine whether a particular fruit is standard or not.

In other cases it is possible obtain images in high contrast using background lighting, where the silhouette of the object is emphasized from the background. Costa et al. (2009) put oranges on a stand lighted at the sides, to determine their shapes. Thus they extracted the polar signature of the contour and calculated the coefficients of Fourier harmonics to describe the size, shape and orientation of each fruit. Menesatti et al. (2008) also used background light to estimate the profile of hazelnuts to discriminate between different cultivars. They used the Fourier ellipse analysis to extract features to estimate the shape using a partial least squares (PLS) model. Antonucci et al. (2012) carried out a similar work to discriminate between different varieties of almond.

The determination of the shape of horticultural products is of interest for a number of reasons, which are detailed in the following sentences: for the improvement and selection of cultivars since the shape of the fruit is necessary for a number of different purposes such as the description of the cultivar in the evaluation of consumer preferences, research into the heritability of the traits of shape in fruits (RASHIDI and GHOLAMI, 2008), analysis of the distribution of mechanical stress in the skin of a fruit crop (CONSIDINE and BROWN, 1981), and the characteristics that determine the relationship between the shape of the fruit and seed yield (NERSON and PARIS, 2001). The sugar beet crop relates not only to the root form and imperfect levels in the soil during harvesting (MILFORD, 1973) but also to the sucrose content (TSIALTAS and MASLARIS, 2010). Another aspect is to determine the relationship between the shape and the maturity of the fruit in products where the shape is used as an index of maturity. The maturity of the mango in some cultivars can be evaluated by examining the position and angle that the shoulder makes with the stem and its attachment to the fruit (THOMPSON, 1996). Peaches and tangerines are considered mature when the fruit shoulders and suture are well developed and filled in, although this criterion has to be accompanied by other indicators such as skin colour (CRISOSTO, 1994). The angle of bananas decreases when they mature (STUDMAN, 2001). The shape of the folds or lobes in sweet peppers is directly related to the quality and health status (NOORDAM, 2005). The compacting of the heads in broccoli and cauliflower can be used as another maturity index, since the broccoli head should ideally have a compact form. The compact form is preferred for the heads because in this case the dew and rainwater drain from the heads, instead of promoting the growth of fungi and bacteria (MAYBERRY, 2000). In the food industry, for example, due to the heat transfer coefficients, the mass depends on the shape and surface area of the object that is being analyzed (SENADEERA et al. 2003; GOÑ et al., 2007). Vegetable processing plants prefer the product to be homogeneous in order to minimize waste and obtain a final product with a uniform shape, which fits in the package well. Manufacturers of French fried potatoes (chips) prefer tubers with oval and elongated shapes, a length of at least $50 \mathrm{~mm}$ and a diameter in the range from 40 to $60 \mathrm{~mm}$ (NIVAP, 2010). The tomato processing industries are interested in the development of varieties with an 
Review: Computer vision applied to the inspection and quality control of fruits and vegetables

SALDAÑA, E. et al.

almost square shape, in order to pack more efficiently, although some companies are interested in developing extremely elongated tomatoes with a cucumber shape. These fruits would be of advantage in the preparation of tomato slices for burgers, where less extremities would have to be discarded (ESPINOZA, 2003).

\subsection{Texture}

The perception of a colour by a computer vision system is different if the surfaces of the objects have different textures. For this reason, the study of the texture is often integrated into colour difference studies, including those used to detect the presence of external defects. The texture can play an important role in image segmentation, since it is an effective tool for troubleshooting in the recognition of standards to automatically inspect fruits and vegetables.

Image segmentation is based on techniques oriented to the pixels (those that process the pixels individually, without considering the neighbours), and is very sensitive to noise or local particularities at the scene. On the other hand the texture-based segmentation of regions of interest requires more complex algorithms besides analyzing the colour, since it also takes into account the spatial relationships between neighbouring pixels to characterize the different regions of an image and detect changes between them (BLASCO et al., 2007a).

Often fruits belonging to the same variety have a high rate of variability in texture and colour, complicating the image analysis. Figure 4 illustrates the wide variation of colours and textures in images of oranges from the same cultivar (cv. "Valencia"). Lopez-Garcia et al. (2010) proposed a method that combines colour and texture information in the Principal Component Analysis (PCA) model for the detection of skin defects in four varieties of citrus, using the RGB values of each pixel and its neighbours (in $3 \times 3$ and $5 \times 5$ windows). With this method they managed to detect $91.5 \%$ of all the defects in the four varieties of oranges and tangerines, with only $3.5 \%$ of false detections.

The co-occurrence matrix of colour and its mathematical characteristics represent one of the most highly used methods to describe texture. Pydipati et al. (2006) used this method to determine whether the texture from HSI colour characteristics could be used in conjunction with other statistical information to identify diseased and healthy leaves from citrus trees, under laboratory conditions. They evaluated samples of healthy citrus leaves and others affected with melanosis and scabies. Zhao et al. (2009) described a similar method to differentiate between healthy skin and five different types of skin damage on images acquired from grapefruit skin with a microscope. Menesatti et al. (2009) used the contrast, homogeneity, second angular moment and correlation of the co-occurrence matrix of gray levels to evaluate the starch content of apples, which is directly related to their maturity. To estimate this they used images from the visible spectrum and the NIR spectrum in the 1000-1700 nm range. Elmasry et al. (2007) evaluated the maturity of strawberries based on pseudo-RGB images (constructed from monochrome images at 450, 500 and $650 \mathrm{~nm}$ ). Ripe fruits had a rougher texture than green ones.

Other less conventional methods using fractal texture characteristics derived from the Fourier spectral analysis, and an example of this was described by Quevedo et al. (2008), who supervised the ripening of bananas detecting the senescence of skin blemishes.

Table 2 summarizes the most recent works related to inspection systems for food products using computer vision. (a)

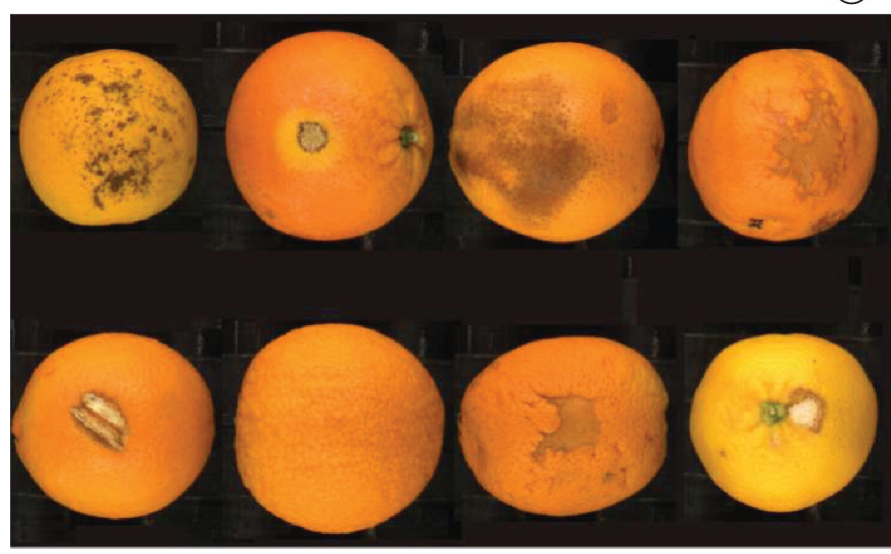

(b)

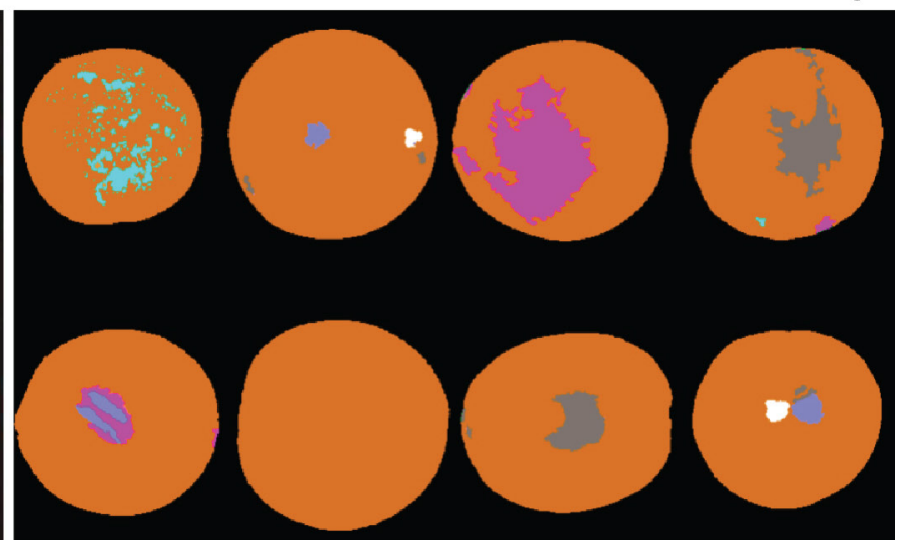

Figure 4. (a) Images of oranges showing different defects, colours and textures on the skin (CUBERO, 2012) and (b) the same images segmented to show the defects found by Cubero (2012). 
Table 2. Fruit and vegetable inspection systems based on computer vision.

\begin{tabular}{|c|c|c|c|}
\hline Product & Imaging System & Application (Technical) & Reference \\
\hline Apple & $\begin{array}{l}\text { CCD camera, UV fluorescent tubes, tungsten } \\
\text { halogen lamps. }\end{array}$ & Defects (ANN) & Ariana et al. (2006a) \\
\hline Apple & Image spectrograph, halogen lamps $45^{\circ}$ & Defects (PLS, SW) & Elmasry et al. (2008) \\
\hline Apple & Image spectrograph, UV lamps $45^{\circ}$. & Defects (ANN) & Elmasry et al. (2009) \\
\hline Apple & Image Spectrograph, UV lamps. & Defects (histogram) & Lefcout and Kim (2006) \\
\hline Apple & Image spectrograph, diffuse halogen lamps. & Defects (PLS) & Lefcout et al. (2006) \\
\hline Apple & Image spectrograph, halogen lamps $45^{\circ}$. & $\begin{array}{c}\text { Colour (RGB), texture } \\
\text { (starch, k-NN, PLS, LDA) }\end{array}$ & Unay and Gosselin (2007) \\
\hline Apple & Image spectrograph, halogen lamps. & Defects (PLS) & Xing et al. (2007) \\
\hline Apple & CCD camera, fluorescent type ring & Colour (RGB, HSI) & Xiaobo et al. (2007) \\
\hline Banana & Camera, fluorescent tubes $45^{\circ}$. & Texture (Fourier fractal descriptors) & Quevedo et al. (2008) \\
\hline Banana & Camera, fluorescent tubes $45^{\circ}$. & Colour (sRGB, HSV, L*a*t*) & Mendoza et al. (2006) \\
\hline Citrus & $\begin{array}{c}\text { Camera } 3 \text { CCDs, fluorescent lamps with } \\
\text { polarized filters. }\end{array}$ & $\begin{array}{c}\text { Colour (RGB, } \mathrm{HSI} \text { ), defects (growing } \\
\text { regions) }\end{array}$ & Blasco et al. (2007a) \\
\hline Citrus & $\begin{array}{c}\text { Camera } 3 \text { CCDs, polarized filters fluorescent } \\
\text { tubes, black light, halogen lamps }\end{array}$ & $\begin{array}{c}\left.\text { Colour (RGB, HSI, } L^{*} a^{*} b^{*}, X Y Z\right) \\
\text { defects (LDA) }\end{array}$ & Blasco et al. (2007b) \\
\hline Citrus & Camera RGB + microscope & $\begin{array}{l}\text { Defects (texture), textures (colour } \\
\text { co-occurrence, SW) }\end{array}$ & Zhao et al. (2009) \\
\hline Citrus & $\begin{array}{c}\text { Camera } 3 \text { CCDs, polarizing filters fluorescent } \\
\text { tubes, black light, halogen lamps }\end{array}$ & $\begin{array}{l}\text { Colour (RGB, HSI), shape (area and } \\
\text { Fourier descriptors), defects (LDA) }\end{array}$ & Blasco et al. (2009b) \\
\hline Citrus & $\begin{array}{c}\text { Camera } 3 \text { CCDs, filters polarized fluorescent } \\
\text { tubes }\end{array}$ & Defects (MIA) & Lopez-Garcia et al. (2010) \\
\hline Cucumber & Image spectrograph, halogen lamps & $\begin{array}{c}\text { Defects } \\
\text { (PCA, band ratio, band differences) }\end{array}$ & Ariana et al. (2006b) \\
\hline Cucumber & Image spectrograph, halogen lamps & Divergence, spectral information & Qin et al. (2009) \\
\hline Lime & CCD camera, UV lamps & Defects (thresholds) & Obenland and Neipp (2005) \\
\hline Tangerine & LCTF, halogen lamps & $\begin{array}{c}\text { Defects } \\
\text { (SW, GALDA, CA, MI, CART, LDA) }\end{array}$ & $\begin{array}{l}\text { Gómez-Sanchis et al. } \\
\text { (2008a) }\end{array}$ \\
\hline Tangerine & LCTF, halogen lamps & Shape (digital elevation) & $\begin{array}{l}\text { Gómez-Sanchis et al. } \\
\text { (2008b) }\end{array}$ \\
\hline Mango & Photo camera, fluorescence diffusion & Colour $\left(L^{*} a^{*} b^{*}\right)$ & Kang and Trujillo (2008) \\
\hline Mushroom & Image spectrograph & Colour $\left(L^{*}\right)$, defects (PCA, LDA) & Gowen et al. (2009) \\
\hline Olive & CCD camera & (RGB, HSV), defects (ANOVA) & Riquelme et al. (2008) \\
\hline Orange & Photo camera, background light & Shape (Fourier descriptors, k-means) & Costa et al. (2009) \\
\hline Orange & Photo camera, UV lamps & Defects (thresholds) & Slaughter et al. (2008) \\
\hline Peach & Multispectral camera, halogen lamps & $\begin{array}{l}\text { Maturation defects } \\
\text { (clustering R / NIR) }\end{array}$ & Lleó et al. (2009) \\
\hline Potato & Photo camera & Defects (AdaBoost) & Barnes et al. (2010) \\
\hline Chips & Photo camera, fluorescent tubes $45^{\circ}$ & Colour $\left(L^{*} a^{*} b^{*}\right)$ & Pedreschi et al. (2006) \\
\hline Chips & Photo camera, fluorescent tubes $45^{\circ}$ & $\begin{array}{l}\text { Colour measurement in confrontation } \\
\text { with sensory evaluators }\end{array}$ & Pedreschi et al. (2011) \\
\hline Starfruit & CCD camera, fluorescent type ring & $\begin{array}{l}\text { Colour }(\mathrm{H}) \text {, shape (Fourier } \\
\text { descriptors) }\end{array}$ & Abdullah et al. (2006) \\
\hline Watermelon & CCD camera & Volume & Koc (2007) \\
\hline Spinach & 3-CCD camera & $\begin{array}{l}\text { Surface changes related to quality } \\
\text { deterioration }\end{array}$ & Lunadei et al. (2012) \\
\hline $\begin{array}{l}\text { Dehydrated } \\
\text { Strawberry }\end{array}$ & D65 Lamp, CCD camera & Attribute changes chromatics & $\begin{array}{l}\text { Agudelo-Laverde et al. } \\
\qquad(2013)\end{array}$ \\
\hline Cabbage & CTR Monitor & Evaluation of freshness & Arce-Lopera et al. (2012) \\
\hline
\end{tabular}

ANN: Artificial Neural Networks, SW: Step by step multivariate analysis; KNN: k-nearest neighbours, LDA: linear discriminant analysis, ANOVA: Analysis of variance; GALDA: Genetic algorithm based on LDA, CA: Analysis of correlations, Ml: mutual information; MIA: image analysis multivariate, UVA: Ultraviolet A, PLS: partial least squares. 
Review: Computer vision applied to the inspection and quality control of fruits and vegetables

SALDAÑA, E. et al.

\section{Conclusions}

The use of technology based on computer vision generates substantial improvements in the quality inspection of processed and unprocessed fruits and vegetables, due to the capabilities of this system in overcoming the limitations of human capacity, allowing for a long-term evaluation of the processes objectively or of appreciating the events taking place outside the visible electromagnetic spectrum. Hyperspectral systems provide information on certain components or damage that may be perceived only at certain wavelengths, and can be used as a tool to develop new computer vision systems adapted for particular purposes. In addition, the online sorting systems allows one to inspect large quantities of fruits or vegetables individually and provide statistics on the batch inspected.

Moreover, the UV and NIR acquisition systems are becoming more easily available. Smart cameras that incorporate image processors are very common in other fields of research and their use is likely to be extended in coming years. IP cameras will also be included soon in remote monitoring applications or inspections based on the web of agrifood processes, including the storage of fruits and vegetables. There is also a stunning development of more powerful image processing techniques causing a gradual increase in computational capacity that encourages the development of more powerful software for image processing in real time. Adaptive algorithms have given promising results in other fields. New advances in pattern recognition and massive data processing should be included in future applications of computer vision to enhance the robustness and accuracy of decisions. There are also new lighting systems that improve the results of image processing with advances in lighting systems. This development should be both spectral and spatial, as it must be able to cover the spectrum analyzed in a uniform manner. LEDs will lead to a great technological leap, contributing both from the point of view of energy efficiency and from the wide variety of solutions they tackle, especially for field applications. Regarding the inspection of processed fruit, few studies have yet been carried out on the application of computer vision, probably due to the low economic interest with respect to fresh fruit and the complexity of these processed fruits. However, the current status of the inspection systems opens new possibilities for the creation of complex and robust algorithms capable of running realtime inspection lines. It is important to begin to develop these algorithms and determine appropriate decision methods adapted to the specific problems of these fruits.

\section{References}

ABDULLAH, M.; MOHAMAD-SALEH, J.; FATHINUL-SYAHIR, A.; MOHD-AZEMI B. Discrimination and classification of fresh-cut starfruits (Averrhoa carambola L.) using automated machine vision system. Journal of Food Engineering, Essex, v. 76, n. 4 , p. 506-523, 2006. http://dx.doi.org/10.1016/j. jfoodeng.2005.05.053.

AGUDELO-LAVERDE, L. M.; SCHEBOR, C.; BUERA, M. D. P. Water content effect on the chromatic attributes of dehydrated strawberries during storage, as evaluated by image analysis, Food Science and Technology, London, v. 55, n. 2, p. 157-152, 2013. http://dx.doi.org/10.1016/j.Iwt.2012.06.022

ALEIXOS, N.; BLASCO, J.; NAVARRO, F.; MOLTO, E. Multispectral inspection of citrus in real-time using machine vision and digital signal processors. Computers and Electronics in Agriculture, Netherlands, v. 33, n. 2, p. 121-137, 2002. http://dx.doi. org/10.1016/S0168-1699(02)00002-9

ANTONUCCI, F.; COSTA, C.; PALLOTTINO, F.; PAGLIA, G.; RIMATORI, V.; DE GIORGIO, D.; MENESATTI, P. Quantitative method for shape description of almond cultivars (Prunusamygdalus batsch). Food and Bioprocess Technology, New York, v. 5, n. 2, p. 768-785, 2012. http://dx.doi.org/10.1007/ s11947-010-0389-2

ARCE-LOPERA, C.; MASUDA, T.; KIMURA, A.; WADA, Y.; OKAJIMA, K. Luminance distribution as a determinant for visual freshness perception: evidence from image analysis of a cabbage leaf. Food Quality and Preference, Barking, v. 27 , n. 2, p. 202-207, 2012. http://dx.doi.org/10.1016/j. foodqual.2012.03.005

ARIANA, D.; GUYER, D.; SHRESTHA, B. Integrating multispectral reflectance and fluorescence imaging for defect detection on apples. Computers and Electronics in Agriculture, Netherlands, v. 50, n. 2, p. 148-161, 2006a. http://dx.doi. org/10.1016/j.compag.2005.10.002.

ARIANA, D.; LU, R.; GUYER, D. Near-infrared hyperspectral reflectance imaging for detection of bruises on pickling cucumbers. Computers and Electronics in Agriculture, Netherlands, v. 53, n. 2, p. 60-70, 2006b. http://dx.doi. org/10.1016/j.compag.2006.04.001.

ARIANA, D. P.; LU, R. Evaluation of internal defect and surface color of whole pickles using hyperspectral imaging. Journal of Food Engineering, Essex, v. 96, n. 4, p. 583-590. 2010. http:// dx.doi.org/10.1016/j.jfoodeng.2009.09.005

BALLARD, D.; BROWN, C. Computer Vision. New Jersey: Prentice-Hall, 1982. p. 252-253.

BARNARD, K.; CARDEI, V.; FUNT, B. A Comparison of computational color constancy algorithms e part i: methodology and experiments with synthesized data. IEEE Transactions on Image Processing, Piscataway, v. 11, n. 9, p. 972-984, 2002.

BARNES, M.; DUCKETT, T.; CIELNIAK, G.; STROUD, G.; HARPER, G. Visual detection of blemishes in potatoes using minimalist boosted classifiers. Journal of Food Engineering, 
Review: Computer vision applied to the inspection and quality control of fruits and vegetables SALDAÑA, E. et al.

Essex, v. 98, n. 3, p. 339-346, 2010. http://dx.doi.org/10.1016/j. jfoodeng.2010.01.010

BEI, L.; DENNIS, G.; MILLER, H.; SPAINE, T.; CARNAHAN, J. Acousto-optic uunable filters: fundamentals and applications as applied to chemical analysis techniques. Progress in Quantum Electronics, United Kingdom, v. 28, n. 2, p. 67-87, 2004. http:// dx.doi.org/10.1016/S0079-6727(03)00083-1

BEYER, M.; HAHN, R.; PESCHEL, S., HARZ, M., KNOCHE, M. Analysing fruit shape in sweet cherry (Prunus avium L.). Scientia Horticulturae, Amsterdam, v. 96, n. 1-4, p. 139-150, 2002. http:// dx.doi.org/10.1016/S0304-4238(02)00123-1

BLASCO, J.; ALEIXOS, N.; MOLTO, E. Machine vision system for automatic quality grading of fruit. Biosystems Engineering, London, v. 85, n. 4, p. 415-423, 2003. http://dx.doi.org/10.1016/ S1537-5110(03)00088-6

BLASCO, J.; ALEIXOS, N.; MOLTO, E. Computer vision detection of peel defects in citrus by means of a region oriented segmentation algorithm. Journal of Food Engineering, Essex, v. 81, n. 3, p. 535-543, 2007a. http://dx.doi.org/10.1016/j. jfoodeng.2006.12.007.

BlAsco, J.; AleiXOS, N.; GOMEZ, J.; MOLTO, E. Citrus sorting by identification of the most common defects using multispectral computer vision. Journal of Food Engineering, Essex, v. 83, n. 3, p. 384-393, 2007b. http://dx.doi.org/10.1016/j. jfoodeng.2007.03.027.

BLASCO, J.; ALEIXOS, N.; CUBERO, S.; GÓMEZ-SANCHÍS, J.; MOLTÓ, E. Automatic sorting of satsuma (Citrus unshiu) segments using computer vision and morphological features. Computers and Electronics in Agriculture, Netherlands, v. 66, n. 1, p. 1-8, 2009a. http://dx.doi.org/10.1016/j.compag.2008.11.006.

BLASCO, J.; ALEIXOS, N.; GOMEZ-SANCHIS, J.; MOLTO, E. Recognition and classification of external skin damage in citrus fruits using multispectral data and morphological features. Biosystems Engineering, London, v. 103, n. 2. p. 137-145, 2009b. http://dx.doi.org/10.1016/j.biosystemseng.2009.03.009.

BLASCO, J.; CUBERO, S.; GOMEZ-SANCHIS, J.; MIRA, P.; MOLTO, E. Development of a machine for the automatic sorting of pomegranate (Punica granatum) arils based on computer vision. Journal of Food Engineering, Essex, v. 90, n. 1, p. 27-34, 2009c. http://dx.doi.org/10.1016/j.jfoodeng.2008.05.035

BROSNAN, T.; SUN, D. Improving quality inspection of food products by computer vision - a review. Journal of Food Engineering, Essex, v. 61, n. 1, p. 3-16, 2004. http://dx.doi. org/10.1016/S0260-8774(03)00183-3

BULANON, D.; BURKS, T.; ALCHANATIS, V. Image fusion of visible and termal images for fruit detection. Biosystems Engineering, London, v. 103, n. 1, p. 12-22, 2009. http://dx.doi. org/10.1016/j.biosystemseng.2009.02.009

CHENG, X.; CHEN, Y. R.; TAO, Y.; WANG C. Y.; KIM M. S.; LEFCOURT, A. M. A novel integrated PCA and FLD method on hyperspectral image feature extraction for cucumber chilling damage inspection. Transactions of the ASAE, St. Joseph, v. 47, n. 4 , p. 1313-1320, 2004.

CONSIDINE, J.; BROWN, K. Physical aspects of fruit growth: theoretical analysis of distribution of surface growth forces in fruit in relation to cracking and splitting. Plant Physiology, Minneapolis, v. 68, n. 2, p. 371-376, 1981.

COSTA, C.; MENESATTI, P.; PAGLIA, G.; PALLOTTINO, F.; AGUZZI, J.; RIMATORI, V.; RUSSO, G.; RECUPERO, S.; RECUPERO, G. Quantitative evaluation of Tarocco sweet orange fruit shape using optoelectronic elliptic Fourier based analysis. Postharvest Biology and Technology, Amsterdam, v. 54, n. 1, p. 38-47, 2009. http://dx.doi.org/10.1016/j. postharvbio.2009.05.001

CRISOSTO, C. Stone fruit maturity indices: a descriptive review. Postharvest News and Information, United Kingdom, v. 5, n. 6, p. 65N-68N, 1994.

CUBERO, S.; ALEIXOS, N.; MOLTO, E.; GOMEZ-SANCHIS, J.; BLASCO, J. Advances in machine vision applications for automatic inspection and quality evaluation of fruits and vegetables. Food and Bioprocess Technology, New York, v. 4, n. 4, p. 487- 504, 2011. http://dx.doi.org/10.1007/s11947011-0585-8

CUBERO, E. Diseño e Implementación de Nuevas Tecnologías Basadas en Visión Artificial para la Inspección no Destructiva de la Calidad de Fruta en Campo y Mínimamente Procesada. 2012. 212p. Tiesis (Tesis Doctoral)- Departamento de Expresión Gráfica Arquitectónica, Universidad Politécnica de Valencia. Valencia, 2012.

DU, C.; SUN, D. Recent developments in the applications of image processing techniques for food quality evaluation. Trends in Food Science \& Technology, Cambridge, v. 15, n. 5, p. 230-249, 2004. http://dx.doi.org/10.1016/j.tifs.2003.10.006

DU, C.; SUN, D. Learning techniques used in computer vision for food quality evaluation: a review. Journal of Food Engineering, Essex, v. 72, n. 1, p. 39-55, 2006. http://dx.doi.org/10.1016/j. jfoodeng.2004.11.017

DUBOIS, S.; GLANZ, F. An autoregressive model approach to two-dimensional shape classification. IEEE Transactions on Pattern Analysis and Machine Intelligence, New York, v. 8 , n. 1, p. 55-66, 1986. 10.1109/TPAMI.1986.4767752.

ELMASRY, G.; WANG, N.; ELSAYED, A.; NGADI, M. Hyperspectral imaging for nondestructive determination of some quality attributes for strawberry. Journal of Food Engineering, Essex, v. 81, n. 1, p. 98-107, 2007. http://dx.doi.org/10.1016/j. jfoodeng.2006.10.016

ELMASRY, G.; WANG, N.; VIGNEAULT, C.; QIAO, J.; ELSAYED, A. Early detection of apple bruises on different background colors using hyperspectral imaging. Food Science and Technology, 
Review: Computer vision applied to the inspection and quality control of fruits and vegetables SALDAÑA, E. et al.

London v. 41, n. 2, p. 337-345, 2008. http://dx.doi.org/10.1016/j. Iwt.2007.02.022

ELMASRY, G.; WANG, N.; VIGNEAULT, C. Detecting chilling injury in Red Delicious apple using hyperspectral imaging and neural networks. Postharvest Biology and Technology, Amsterdam, v. 52, n. 1, p. 1-8, 2009. http://dx.doi.org/10.1016/j. postharvbio.2008.11.008

ESPINOZA, M. Researcher Seeks to Solve Tomato Shape Riddle, Develop new Varieties. Ohio State University Extension, 2003. Disponível em: <http://www.ag.ohio-state.edu/ news/ story. php?id=2673>. Acesso em: 03 janeiro 2013.

EVANS, M.; THAI, C.; GRANT, J. Development of a spectral imaging system based on a liquid crystal tunable filter. Transactions of the ASAE, St. Joseph, v. 41, n. 6, p. 18451852, 1998.

FATHI, M.; MOHEBBI, M.; ALIRAZAVI, S. Application of image analysis and artificial neural network to predict mass transfer kinetics and color changes of osmotically dehydrated kiwifruit. Food and Bioprocess Technology, New York, v. 4, n. 8, p. 13571366, 2011

FERNANDEZ, L.; CASTILLERO, C.; AGUILERA, J. An application of image analysis to dehydration of apple discs. Journal of Food Engineering, Essex, v. 67, n. 1-2, p. 185-193, 2005. http://dx.doi. org/10.1016/j.jfoodeng.2004.05.070

FORSYTH, D.; PONCE, J. Computer Vision: A Modern Approach. New Jersey: Prentice Hall. 2003. p. 720.

GARDNER, J. Comparison of calibration methods for tristimulus colorimeters. Journal of Research of the National Institute of Standards and Technology, Gaithersburg, v. 112, n. 3, p. 129138, 2007. http://www.nist.gov/jres.

GÓMEZ-SANCHIS, J.; GOMEZ-CHOVA, L.; ALEIXOS, N.; CAMPS-VALLS, G.; MONTESINOS, C.; MOLTO, E.; BLASCO, J. Hyperspectral system for early detection of rottenness caused by Penicillium digitatum in mandarins. Journal of Food Engineering, Essex, v. 89, n. 1, p. 80-86, 2008a. http://dx.doi. org/10.1016/j.jfoodeng.2008.04.009

GÓMEZ-SANCHIS, J.; MOLTÓ, E.; CAMPS-VALLS, G.; GÓMEZCHOVA, L.; ALEIXOS, N.; BLASCO, J. Automatic correction of the effects of the light source on spherical objects. An application to the analysis of hyperspectral images of citrus fruits. Journal of Food Engineering, Essex, v. 85, n. 2, p. 191-200, 2008b. http://dx.doi.org/10.1016/j.jfoodeng.2007.06.036

GOÑI, S.; PURLIS, E.; SALVADORI, V. Three-dimensional reconstruction of irregular foodstuffs. Journal of Food Engineering, Essex, v. 82, n. 4, p. 536-547, 2007. http://dx.doi. org/10.1016/j.jfoodeng.2007.03.021

GOWEN, A.; TAGHIZADEH, M.; O'DONNELL, C. Identification of mushrooms subjected to freeze damage using hyperspectral imaging. Journal of Food Engineering, Essex, v. 93, n. 1, p. 7-12, 2009. http://dx. doi.org/10.1016/j.jfoodeng.2008.12.021
GUNASEKARAN, S. Computer vision technology for food quality assurance. Trends in Food Science \& Technology, Cambridge, v. 7, n. 8, p. 245-256, 1996. http://dx.doi.org/10.1016/09242244(96)10028-5

GUO, F.; CAO, Q.; NAGATA, M.; Tallada, J. G. NIR hyperspectral imaging measurement of sugar content in peach using PLS regression. Journal of Shanghai Jiao Tong University (Science), Shanghai, v. E-12, n. 5, p. 597-601, 2007.

HECHT, E. Optics. 3 ed. Massachusetts: Addison Wesley Longman, 1998. 694 p.

HERNÁNDEZ-SÁNCHEZ, N.; HILLS, B.; BARREIRO, P.; MARIGHETO, N. A NMR study on internal browning in pears. Postharvest Biology and Technology, Amsterdam, v. 44, n. 3, p. 260-270, 2007. http://dx.doi.org/10.1016/j. postharvbio.2007.01.002.

HOFFMAN, G. CIE Colour Space, 2000. Disponível em: <http:// www.fho-emden.de/ hoffmann /ciexyz29082000.pdf>. Acesso em: 03 janeiro 2013.

HOFSHI, R.; ARPAIA, M. Avocado fruit abnormalities and defects revisited. California Avocado Society Yearbook, Temecula, v. 86, p. 147-162, 2002.

HUNTERLAB. Application Note: Hunter L,a,b Versus CIE 1976 L*a*b*. HunterLab: The color management Company, v. 13, n. 2, 2001. Disponível em: <http://www.hunterlab.com/appnotes/ an02_01.pdf>. Acesso em: 03 janeiro 2013.

HURLBERT, A. Colour constancy. Current Biology, London, v. 17, n. 21, p. R906-R907. 2007

JACKMAN, P.; SUN, D.; ALLEN, P. Recent advances in the use of computer vision technology in the quality assessment of fresh meats. Trends in Food Science \& Technology, Cambridge, v. 22, n. 4, p. 185-197, 2011. http://dx.doi.org/10.1016/j. tifs.2011.01.008

JIMÉNEZ-CUESTA, M.; CUQUERELLA, J.; MARTINEZ-JAVEGA, $J$. Determination of a color index for citrus fruit degreening. Proceedings of the International Society of Citriculture, Tokyo, v. 2, p. 750-753, 1981.

KANG, S.; TRUJILLO, F. Colour vision system evaluation of bicolour fruit: a case study with 'B74' mango. Postharvest Biology and Technology, Amsterdam, v. 49, n. 1, p. 77-85, 2008. http://dx.doi.org/10.1016/j.postharvbio.2007.12.011.

KARIMI, Y.; MAFTOONAZAD, N.; RAMASWAMY, H.; PRASHER S.; MARCOTTE, M. Application of hyperspectral technique for color classification avocados subjected to different treatments. Food and Bioprocess Technology, New York, v. 5, n. 1, p. 252-264, 2009.

KIM, M.; CHEN, Y.; MEHL, P. Hyperspectral reflectance and fluorescence imaging system for food quality and safety. Transactions of the ASAE, St. Joseph, v. 44, n. 3, p. 721-729, 2001. 
Review: Computer vision applied to the inspection and quality control of fruits and vegetables

SALDAÑA, E. et al.

KIM, M.; CHEN, Y.; CHO, B.; CHAO, K.; YANG, C.; LEFCOURT, A.; CHAN, D. Hyperspectral reflectance and fluorescence line-scan imaging for online defect and fecal contamination inspection of apples. Sensing and Instrumentation for Food Quality and Safety, Germany, v.1, n. 3, p. 151-159, 2007.

KOC, A. Determination of watermelon volume using ellipsoid approximation and image processing. Postharvest Biology and Technology, Amsterdam, v. 45, n. 3, p. 366-371, 2007. http:// dx.doi.org/10.1016/j.postharvbio.2007.03.010

KONDO, N. Automation on fruit and vegetable grading system and food traceability. Trends in Food Science and Technology, Cambridge, v. 21, n. 3, p. 145-152, 2010. http://dx.doi. org/10.1016/j.tifs.2009.09.002.

LEFCOUT, A.; KIM, M. Technique for normalizing intensity histograms of images when the approximate size of the target is known: detection of feces on apples using fluorescence imaging. Computers and Electronics in Agriculture, Netherlands, v. 50, n. 2, p. 135-147, 2006

LEFCOUT, A.; KIM, M.; CHEN Y-R.; KANG B. Systematic approach for using hyperspectral imaging data to develop multispectral imagining systems: Detection of feces on apples. Computers and Electronics in Agriculture, Netherlands, v. 54, n. 1, p. 22-35, 2006. http://dx.doi.org/10.1016/j.compag.2006.06.002.

LEÓN, K.; DOMINGO, M.; PEDRESCHI, F.; LEON, J. Color measurement in $L^{*} a^{*} b^{*}$ units from RGB digital images. Food Research International, Oxford, v. 39, n. 10, p. 1084-1091, 2006. http://dx.doi.org/10.1016/j.foodres.2006.03.006

LIMING, X.; YANCHAO, Z. Automated strawberry grading system based on image processing. Computers and Electronics in Agriculture, Netherlands, v. 71, n. 1, p. S32-S39, 2010. http:// dx.doi.org/10.1016/j.compag.2009.09.013

LI, B.; XU, D.; FENG, S. H. Illumination estimation based on color invariant. Chinese Journal of Electronics, China, v. 18, n. 3, p. 431-434. 2009.

LLEÓ, L.; BARREIRO, P.; RUIZ-ALTISENT, M.; HERRERO, A. Multispectral images of peach related to firmness and maturity at harvest. Journal of Food Engineering, Essex, v. 93, n. 2, p. 229-235, 2009. http://dx.doi.org/10.1016/j. jfoodeng.2009.01.028

LORENTE, D.; ALEIXOS, N.; GOMEZ-SANCHIS, J.; CUBERO, S.; GARCIA-NAVARRETE, O.; BLASCO, J. Recent advances and applications of hyperspectral imaging for fruit and vegetable quality assessment. Food and Bioprocess Technology, New York, v. 5, n. 4, p. 1121-1142, 2012.

LOPEZ-GARCIA, F.; ANDREU-GARCIA, A.; BLASCO, J.; ALEIXOS, N.; VALIENTE, J. Automatic detection of skin defects in citrus fruits using a multivariate image analysis approach. Computers and Electronics in Agriculture, Netherlands, v. 71, n. 2, p. 189-197, 2010. http://dx.doi.org/10.1016/j. compag.2010.02.001
LUNADEI, L.; DIEZMA, B.; LLEÓ, L.; RUIZ-GARCIA, L.; CANTALAPIEDRA, M.; RUIZ, A. Monitoring of fresh-cut spinach leaves through a multispectral vision system. Postharvest Biology and Technology, Amsterdam, v. 63, n. 1, p. 74-84, 2012. http://dx.doi.org/10.1016/j.postharvbio.2011.08.004

MAYBERRY, K. Vegetable Crops Guidelines: Sample Cost to Establish and Produce Broccoli. University of California. 2000. Disponível em: <http://coststudies.ucdavis.edu/files/broccoli. pdf>. Acesso em: 13 dezembro 2013.

MENDOZA, F.; DEJMEK, P.; AGUILERA, J. Calibrated color measurements of agricultural foods using image analysis. Postharvest Biology and Technology, Amsterdam, v. 41, n. 3, p. 285-295, 2006. http://dx.doi.org/10.1016/j. postharvbio. 2006.04 .004

MENESATTI, P.; COSTA, C.; PAGLIA, G.; PALLOTTINO, F.; D'ANDREA, S.; RIMATORI, V.; AGUZZI, J. Shape-based methodology for multivariate discrimination among Italian hazelnut cultivars. Biosystems Engineering, London, v. 101, n. 4, p. 417-424, 2008. http://dx.doi.org/10.1016/j. biosystemseng.2008.09.013

MENESATTI, P.; ZANELLA, A.; D'ANDREA, S.; COSTA, C.; PAGLIA, G.; PALLOTTINO, F. Supervised multivariate analysis of hyper-spectral NIR images to evaluate the starch index of apples. Food and Bioprocess Technology, New York, v. 2, n. 3, p. 308-314, 2009.

MENESATTI, P.; ANGELINI, C.; PALLOTTINO, F.; ANTONUCCI, F.; AGUZZI, J.; COSTA, C. RGB color calibration for quantitative image analysis: the "3D thin-plate spline" warping approach. Sensors (Bassel), Switzerland, v. 12, n.6, p. 7063-7079, 2012.

MILCZAREK, R.; SALTVEIT, M.; GARVEY, T.; MCCARTHY, M. Assessment of tomato pericarp mechanical damage using multivariate analysis of magnetic resonance images. Postharvest Biology and Technology, Amsterdam, v. 52, n. 2, p. 189-195, 2009. http://dx.doi.org/10.1016/j. postharvbio.2009.01.002

MILFORD, G. The growth and development of the storage root of sugar beet. Annals of Applied Biology, Warwick, v. 75, n. 3 , p. 427-438, 1973.

NERSON, H., PARIS, H.S. Relationship between fruit shape and seed yield in Cucurbita pepo. Cucurbit Genetics Cooperative Report, North Carolina, v. 24, p. 82-86, 2001.

NICOLAI, B.; LOTZE, E.; PEIRS, A.; SCHEERLINCK, N.; THERON, K. Non-destructive measurement of bitter pit in apple fruit using NIR hyperspectral imaging. Postharvest Biology and Technology, Amsterdam, v. 40, n. 1, p. 1-6, 2006. http://dx.doi. org/10.1016/j.postharvbio.2005.12.006

NIVAP, H. (Netherlands Potato Consultative Foundation). Tuber characteristics determining quality, 2010. Disponível em: <http://www.nivaa.nl/uk/about_potatoes/agronomy/on_the_road_ to_potato_processing/tuber_characteristics>. Acesso em: 03 janeiro 2013. 
Review: Computer vision applied to the inspection and quality control of fruits and vegetables SALDAÑA, E. et al.

$\mathrm{NOH}$, H. K.; LU, R.Hyperspectral laser-induced fluorescence imaging for assessing apple fruit quality. Postharvest Biology and Technology, Amsterdam, v. 43, n. 2, p.193-201, 2007. http:// dx.doi.org/10.1016/j.postharvbio.2006.09.006

NOORDAM, J. Innovative applications in the Agro and Food Industry. Third European Machine Vision Association Conference. 2005. Disponível em: <http:// www.greenvision. wur.nl/documents/publicaties/in_de_pers/Algemeen/2005_04_ EMVABusinessConference_Innovative\%20Applications $\% 20$ in\%20the\%20Agro\%20and\%20Food\%20industry.pdf>. Acesso em: 03 janeiro 2013.

OBENLAND, D.; NEIPP, P. Chlorophyll fluorescence imaging allows early detection and localization of lemon rind injury following hot water treatment. Hortscience, Alexandria, v. 40, n. 6, p. 1821-1823, 2005.

OKAMOTO, H.; LEE, W. Green citrus detection using hyperspectral imaging. Computers and Electronics in Agriculture, Netherlands, v. 66, n. 2, p. 201-208, 2009. http:// dx.doi.org/10.1016/j.compag.2009.02.004

PASCHOS, G. Perceptually uniform color spaces for color texture analysis: an empirical evaluation. IEEE Transactions on Image Processing, Piscataway, v. 10, n. 10, p. 932-937. 2001.

PAULUS, I.; BUSSCHER, R.; SCHREVENS, E. Use of image analysis to investigate human quality classification of apples. Journal Agricultural Engineering Research, Egyptian, v. 68, n. 4, p. 341-53, 1997. http://dx.doi.org/10.1006/jaer.1997.0210.

PEDRESCHI, F.; LEON, J.; MERY, D.; MOYANO, P. Development of a computer visión system to measure the color of potato chips. Food Research International, Oxford, v. 39, n. 10, p. 10921098, 2006. http://dx.doi.org/10.1016/j.foodres.2006.03.009

PEDRESCHI, F.; MERY, D.; BUNGER, A.; YANEZ, V. Computer vision classification of potato chips by color. Journal of Food Process Engineering, Essex, v. 34, n. 5, p. 1714-1728, 2011.

PENG, Y.; LU, R. Analysis of spatially resolved hyperspectral scattering images for assessing apple fruit firmness and soluble solids content. Postharvest Biology and Technology, Amsterdam, v. 48, n. 1, p. 52-62, 2008. http://dx.doi. org/10.1016/j.postharvbio.2007.09.019

PETERSON, C. How it works: the charge-coupled device or CCD. Journal of Young Investigators. Georgetown University. 2001. Disponível em: <http://www.jyi.org/volumes/volume3/issue1/ features/ peterson.html>. Acesso em: 03 janeiro 2013.

POLDER, G.; VAN DER HEIJDEN, G.; KEIZER, L.; YOUNG, I. Calibration and characterization of spectral imaging systems. Journal Near Infrared Spectroscopy, Sussex, v. 4548, n. 11, p. 193-210, 2001.

PYDIPATI, R.; BURKS, T.; LEE, W. Identification of citrus disease using color texture features and discriminant analysis. Computers and Electronics in Agriculture, Netherlands, v. 52, n. 1-2, p. 49-59, 2006. http://dx.doi.org/10.1016/j. compag.2006.01.004

QIN, J.; BURKS, T.; RITENOUR, M.; BONN, W. Detection of citrus canker using hyperspectral reflectance imaging with spectral information divergence. Journal of Food Engineering, Essex, v. 93, n. 2, p. 183-191, 2009. http://dx.doi.org/10.1016/j. jfoodeng.2009.01.014

QUEVEDO, R.; MENDOZA, F.; AGUILERA, J.; CHANONA, J.; GUTIERREZ-LOPEZ, G. Determination of senescent spotting in banana (Musa cavendish) using fractal texture Fourier image. Journal of Food Engineering, Essex, v. 84, n. 45, p. 509-515, 2008. http://dx.doi.org/10.1016/j.jfoodeng.2007.06.013

RASHIDI, M.; GHOLAMI, M. Classification of fruit shape in kiwifruit using the analysis of geometrical attributes. American-Eurasian Journal of Agricultural and Environmental Sciences, Deira, v. 3, n. 2, p. 258-263, 2008.

RIQUELME, M.; BARREIRO, P.; RUIZ-ALTISENT, M.; VALERO, C. Olive classification according to external damage using image analysis. Journal of Food Engineering, Essex, v. 87, n. 9, p. 371-379, 2008. http://dx.doi.org/10.1016/j. jfoodeng.2007.12.018

SADRNIA, H.; RAJABIPOUR, A.; JAFARY, A.; JAVADI, A.; MOSTOFI, Y. Classification and analysis of fruit shapes in long type watermelon using image processing. International Journal of Agriculture and Biology, Washington, v. 9, n. 1, p. 68-70, 2007.

SAFREN, O.; ALCHANATIS, V.; OSTROVSKY, V.; LEVI, O. Detection of green apples in hyperspectral images of apple-tree foliage using machine vision. Transactions of the ASABE, St. Joseph, v. 50, n. 6, p. 2303-2313, 2007

SALDAÑA, E.; SICHE, R.; HUAMÁN, R.; LUJÁN, M.; CASTRO, W.; QUEVEDO, R. Computer vision system in real-time for color determination on flat surface food. Scientia Agropecuaria, Perú, v. 4, n. 1, p. 55-63, 2013.

SENADEERA, W.; BHANDARI, B.; YOUNG, G.; WIJESINGHE, $B$. Influence of shapes of selected vegetable materials on drying kinetics during fluidized bed drying. Journal of Food Engineering, Essex, v. 58, n. 3, p. 277-283, 2003. http://dx.doi. org/10.1016/S0260-8774(02)00386-2

SLAUGHTER, D.; OBENLAND, D.; THOMPSON, J.; ARPAIA, M.; MARGOSAN, D. Non-destructive freeze damage detection in oranges using machine vision and ultraviolet fluorescence. Postharvest Biology and Technology, Amsterdam, v. 48, n. 3, p. 341-346, 2008. http://dx.doi.org/10.1016/j. postharvbio.2007.09.012.

STOKES, M.; ANDERSON, M.; CHANDRASEKAR, S.; MOTTA, R. A. Standard default color space for the internet: sRGB. 1996. Disponível em: <http://www.color.org/sRGB.xalter>. Acesso em: 08 October 2012. 
Review: Computer vision applied to the inspection and quality control of fruits and vegetables

SALDAÑA, E. et al.

STUDMAN, C. Computers and electronics in postharvest technology - a review. Computers and Electronics in Agriculture, Netherlands, v. 30, n. 1-3, p. 109-124, 2001. http:// dx.doi.org/10.1016/S0168-1699(00)00160-5

SUN, D. Inspecting pizza topping percentage and distribution by a computer vision method. Journal of Food Engineering, Essex, v. 44, n. 4, p. 245-249, 2000. http://dx.doi.org/10.1016/ S0260-8774(00)00024-8

SUN, D.; BROSNAN, T. Pizza quality evaluation using computer vision - part 1 - Pizza base and sauce spread. Journal of Food Engineering, Essex, v. 57, n. 1, p. 81-89., 2003. http://dx.doi. org/10.1016/S0260-8774(02)00275-3

SUN, D. Computer vision technology for food quality evaluation. Academic Press. 1 ed. London: Elsevier Science, 2007. 600 p.

SUN, D. Hyperspectral Imaging for Food Quality Analysis and Control. Academic Press. London: Elsevier Science, 2010. $496 \mathrm{p}$.

THOMPSON, A.K. Postharvest Technology of Fruit and Vegetables. Oxford: Blackwell, 1996. 410 p.

THROOP, J.; ANESHANSLEY, D.; ANGER, W.; PETERSON D. Quality evaluation of apples based on surface defects: development of an automated inspection system. Postharvest Biology and Technology, Amsterdam, v. 36, n. 3, p. 281-90, 2005. http://dx.doi.org/10.1016/j.postharvbio.2005.01.004

TSIALTAS, J.; MASLARIS, N. Sugar beet root shape and its relation with yield and quality. Sugar Tech, India, v. 12, n. 1, p. 47-52, 2010.

UNAY, D.; GOSSELIN, B. Automatic defect segmentation of 'Jonagold' apples on multi-spectral images: a comparative study. Postharvest Biology and Technology, Amsterdam, v. 42, n. 3, p. 271-279, 2006. http://dx.doi.org/10.1016/j. postharvbio.2006.06.010

UNAY, D.; GOSSELIN, B. Stem and calyx recognition on 'Jonagold' apples by pattern recognition. Journal of Food Engineering, Essex, v. 78, n. 2, p. 597-605, 2007. http://dx.doi. org/10.1016/j.jfoodeng.2005.10.038

VAN POUCKE, S.; HAEGHEN, Y. V.; VISSERS, K.; MEERT, T.; JORENS, P. Automatic colorimetric calibration of human wounds. BMC Medical Imaging, London, v. 10, n. 7, p. 1-11, 2010. http:// dx.doi.org/10.1186/1471-2342-10-7

XIAOBO, Z.; JIEWEN, Z.; YANXIAO, L. Apple color grading based on organization feature parameters. Pattern Recognition
Letters, Amsterdam, v. 28, n. 15, p. 2046-2053, 2007. http:// dx.doi.org/10.1016/j.patrec.2007.06.001

XING, J., De BAERDEMAEKER, J. Bruise detection on "Jonagold" apples using hyperspectral imaging. Postharvest Biology and Technology, Amsterdam, v. 37, n. 2, p. 152-162. 2005. http:// dx.doi.org/10.1016/j.postharvbio.2005.02.015

XING, J.; JANCSOK, P.; DE BAERDEMAEKER, J. Stem-end/ calyx identification on apples using contour analysis in multispectral images. Biosystems Engineering, London, v. 96, n. 2, p. 231-237, 2007. http://dx.doi.org/10.1016/j. biosystemseng.2006.10.018

XUL, Q.; ZOU, X.; ZHAO, J. On-line detection of defects on fruit by machinevision systems based on three-color-cameras systems. Computer and Computing Technologies in Agriculture II, Wuyishan, v. 295, p. 2231-2238, 2009. http:// dx.doi.org/10.1007/978-1-4419-0213-9_75

YING, Y.; JING, H.; TAO, Y.; ZHANG, N.; Detecting stem and shape of pears using Fourier transformation and an artificial neural network. Transactions of the ASAE, St. Joseph, v. 46, n. 1, p. 157-162, 2003.

ZHAO, X.; BURKS, T.; QIN, J.; RITENOUR, M. Digital microscopic imaging for citrus peel disease classification using color texture features. Applied Engineering in Agriculture, St. Joseph, v. 25, n. 5, p. 769-776, 2009.

ZHENG, C.; SUN, D.; ZHENG, L. Recent applications of image texture for evaluation of food qualities e a review. Trends in Food Science \& Technology, Cambridge, V. 17, n. 3, p. 113-128, 2006a. http://dx.doi.org/10.1016/j.tifs.2005.11.006

ZHENG, C.; SUN, D.; ZHENG, L. Recent developments and applications of image features for food quality evaluation and inspection e a review. Trends in Food Science \& Technology, Cambridge, v. 17, n. 12, p. 642-655, 2006b. http://dx.doi. org/10.1016/j.tifs.2006.06.005

ZUDE, M. Optical Monitoring of Fresh and Processed Agricultural Crops. Boca Raton: CRC Press, 2008. 576 p. 